\title{
La anemia simbólica como epicentro antropológico de la desacramentalización contemporánea
}

Alfonso Vives Cuesta

RESUMEN: Se propone una definición omnicompresiva de la antropología de los sacramentos cristianos como solución de sentido ante la "anemia simbólica" que ha experimentado la praxis sacramental contemporánea como mediación, de acceso y respuesta, en la experiencia del encuentro interpersonal con Dios. Esto supone un debilitamiento de la experiencia de la fe subjetiva (fides qua) derivada de una presentación velada de la verdadera esencia simbólica del lenguaje cristiano ausente de los mecanismos de comunicación de las mediaciones sacramentales tradicionales. Esta finalidad exige un análisis, en clave antropológica, de la dimensión simbólica del hombre y de la religión que clarifique la "desacramentalización" actual. PALABRAS CLAVE: anemia simbólica, práctica sacramental, experiencia de Dios.

ABSTRACT:We suggest an all-inclusive definition of Anthropolgy of the christian sacraments as a solution to the "symbolic anaemia" experienced by sacramental practice as a mean of access to God.This implies the weakening of personal experience of the Mystery for lack of the sacramental symbolic language. So today we need a deeper analysis of the symbolic dimension of religion and of man to understand and correct the current weakening of sacramental practice. KEY WORDS: Symbolic anaemia, sacramental practice, religious language.

\section{1.- Advertencias metodológicas preliminares}

El acceso proposicional o discursivo propio del lenguaje que nos permite hablar de "sacramentos" concretos o de "sacramentalidad" genérica está claramente limitado por la realidad trascendente en lo inmanente hacia 
la que estos apuntan icónica y mediadamente. Cuando se habla de "sacramento", por tanto, hemos de partir de la especial naturaleza a la que se alude con este vocablo. En primer lugar se exige un acotamiento terminológico por la propia naturaleza del "ente" sacramental. Dado que con la voz "sacramento" designamos realidades muy distintas y de distintos niveles (septenario, sacramentos mayores, menores, acciones sacramentales, etc. $)^{1}$, hemos de hablar de la unidad en la pluralidad manifiesta $y$, al mismo tiempo, por lo que respecta a su carácter sígnico, de la manifestación inmanente de lo más densamente trascendente (per invisibilia ad visibilia). Dadas estas premisas, a la hora de aludir a la idea de sacramento no nos queda más remedio que optar por un lenguaje que tenga en cuenta el principio de analogia entis, razonamiento en virtud del cual se puede hacer abstracción del común denominador de todas aquellas realidades, que en su diversidad equívoca, mantienen un sentido unívoco. Esa misma capacidad analógica que se observa a nivel ontológico, se puede aplicar al nivel sacramental, de manera que para la descripción de toda esta realidad sea necesario hablar de una "analogía sacramental"2.

Por otra parte, el camino analógico da muestras de seguridad hermenéutica, pues hay que tener en cuenta los principios del funcionamiento del pensamiento humano, que, a través de sucesivas operaciones cognitivas que tienen en común un progresivo grado de traslación, permite la creación de pensamientos de mayor abstracción a partir de entidades más inmediatamente aprehensibles sensorialmente. Esta secuencia mental está basada tanto en el principio de analogía aplicado a los signos visibles como en el principio de prototipicidad que funciona atribuyendo rasgos muy generales y compartidos a un haz de realidades diversas que tienen un "aire de familia" por el hecho de participar al mismo tipo, categoría o grupo de entidades. Dicho esto, y en consonancia con la naturaleza mistagógica que inunda la entraña sacramental, parece necesario partir del dato concreto que nos ofrece la praxis celebrativa y litúrgica de los sacramentos, para llegar a de-

${ }^{1}$ ConGAR, Y. ya confirmó los datos tradicionales sobre la conveniencia teológica y ecuménica de distinguir diferentes grados jerárquicos de sacramentalidad existentes en la realidad en su artículo "La idea de sacramentos mayores o principales": Concilium 4 (1968) 24-37.

${ }^{2}$ El Documento DE DOMBes “L' Esprit-Saint, 1 Eglise et les Sacraments” (Taizé 1979), publicado posteriormente en Diálogo Ecuménico 15 (1980), pp. 427-462. El tema de la analogía sacramental descuella en este documento ecuménico y está igualmente presente en obras de otros autores españoles como CoDINA V. (1979): "Analogía sacramental: de la Eucaristía a la solidaridad", Estudios Eclesiásticos 54, pp.335-362 y, más recientemente, en BoROBIO, D. (2012): Historia y teología comparada de los sacramentos: el principio de la analogía sacramental, Sígueme: Salamanca. 
finiciones sistemáticas especulativamente más elaboradas. Este es el prerrequisito teórico del que partirá nuestra investigación sobre la dimensión antropológica de la crisis sacramental contemporánea.

Establecidas estas premisas, en una introducción teórica merece la pena señalar el concepto sacramental en toda su amplitud conceptual, máxime cuando nos enfrentamos a una realidad compleja que va a ser abordada desde una perspectiva antropológica y socio-cultural.

El alcance complexivo que exige la perspectiva que vamos a manejar de la sacramentalidad es más accesible desde la realidad que supone una definición proporcionalmente extensa, abarcativa y que se ajusta bien al principio de analogía sacramental. La revaloración de la argumentación escriturística y patrística que redescubre el Concilio Vaticano II permite una sobredimensión del alcance de la definición de "sacramento" que tiene por referente a Cristo y a la Iglesia como sacramentos vivos, ampliándolos a los principales referentes que intervienen en la economía sacramental: Cristo, Iglesia, pero también el hombre y el mundo creado ${ }^{3}$. Esta definición opera fielmente sobre las definiciones tradicionales de S. Agustín ("signo de una realidad sagrada") o de la Escolástica ("signo visible de una realidad invisible") y las amplía como resultado de la desproporción analógica que supone hablar de una realidad sacramental encajada en las necesidades de autorrealización existencial del hombre religioso moderno en su extralimitación personal de apertura al Misterio.

La presente reflexión sobre los sacramentos medita, por tanto, en un ámbito mixto antropológico-existencial y teológico simultáneamente, puesto que partimos del hecho de encontrar una hermenéutica que asume e integra la historicidad del hombre. Es el hombre contemporáneo en su percepción concreta de las acciones sacramentales que le ofrece la Iglesia quien mejor nos puede orientar en la percepción religiosa y, por tanto, simbólica de lo sagrado. Por su parte, la posición de la teología sacramental, en su misión original de doble alcance en las relaciones de lo humano y lo divino, debe desarrollar su búsqueda infatigable de sentido en esa maraña simbólica que se le presenta al hombre. La propia hermenéutica teológica (fides quaerens intellectum) favorece la comprensión como búsqueda infatigable de sentido. Realizar afirmaciones tratando a la realidad misteriosa como objetivable y sobredimensionar esa comprensión avanzando hasta límites insospechados para lo empírico constituye la experiencia del Misterio en cuyo regazo se asienta cómodamente el lenguaje simbólico.

\footnotetext{
${ }^{3}$ Entre otras muchas alusiones a esto cf. LG 1, 8, 38, 48: SC 5-6; GS 12, 14, 36. Cf. también la información que ofrece el CIC bajo el epígrafe "Economía Sacramental", nn. 11131209.
} 
La vivencia sacramental predispone al sujeto a penetrar en el conocimiento de sus arcanos mediatizando signos externos, más o menos ritualizados, en los que se descubre un conocimiento superior, vertido hacia las "cosas divinas". La honda experiencia sacramental a lo largo de la historia del cristianismo nos ha persuadido de que se trata de una fuerte vivencia en la que se rememora, reconstruye y se reactiva la realidad plenificante del encuentro entre Dios y el hombre. El acercamiento a esta dimensión del ser humano no puede quedar limitado a una enseñanza doctrinal, por sancionada que esta se encuentre en el acervo magisterial. Es más, será sobre ese material tradicional sobre el que deberemos construir y recrear una nueva dimensión experiencial de los sacramentos en su tarea mediadora de encuentro histórico-existencial con el hombre. Pero teniendo siempre en cuenta los límites que siempre interpone el hecho de que todo análisis con intención explicativa de la dimensión sacramental no puede ser efectivo sin el recurso de una óptica antropológica que nos permite penetrar en las reglas del juego que determinan el ámbito histórico-cultural de intervención del hombre inmanente con el Otro inobjetivable y trascendente. En este sentido la siguiente reflexión es palmaria y recoge todos los ámbitos en que se puede articular el fenómeno sacramental:

Estudiar un sacramento significa comprenderlo desde una situación vital (antropología simbólica) en un contexto cultural e histórico (antropología cultural), que tiene en cuenta los datos de la realidad y el contexto social (sociología), así como las reacciones y mecanismos personales y colectivos ante esta situación (psicología) detentando los fenómenos religiosos que en relación con esta situación se han dado y se dan hoy (fenomenología e historia de las religiones) y profundizando en la riqueza de la experiencia límite que se viven en la llamada a la trascendencia o en la revelación de lo divino desde la misteriosidad de lo humano (metafísica y teodicea).

Limitándonos al ámbito antropológico, la presente reflexión pretende dar algunas respuestas o claves interpretativas a la visible desacramentalización que afecta a la experiencia vivencia de los sacramentos, especialmente, tomando como punto de referencia la pérdida de la hermenéutica simbólica, característica de este período y que afecta con especial virulencia al lenguaje religioso en cualesquiera de sus manifestaciones concretas.

\subsection{LO SIMBÓLICO EN LO SACRAMENTAL}

¿Por qué estudiar los sacramentos como filtro para acceder al conocimiento más verdadero del hombre en su acceso a la experiencia de Dios? 
Sencillamente porque los sacramentos fueron instituidos por Cristo, desarrollados y madurados por la tradición eclesiástica en conexión con las necesidades de los tiempos y celebrados vicariamente por los agentes de pastoral de la Iglesia dentro de una dimensión simbólica que permite su comunicación con lo externo. De este modo, partiendo de una realidad externa y dualmente significante, la traslación simbólica nos remite a una realidad significada (res veritatis) que le permite al hombre, en función del principio de analogía, penetrar y participar dimensionadamente en lo Otro. Por otra parte, el hombre de hoy, como analizaremos en detalle, percibe la realidad desde su definitoria subjetividad simbólica y la expresa en virtud de un instrumento lingüístico de base originariamente simbólico y no exclusivamente lógico-racional. Una visión más espiritualizada de este asunto nos podría refutar con la pregunta ¿por qué tanto énfasis en el aspecto simbólico de lo religioso en la codificación de la evidencia inmanente de los sacramentos? Ciertamente, la respuesta nos la ofrece la propia vertebración narrativa del ritual. El sacramento queda vertebrado en el lenguaje narrativo de la experiencia de un encuentro interrelacional, como bien ha demostrado la denominada teología-antropología dialéctica. Los hombres, en cuanto creaturas, están convocados, a través de su connatural relación encarnatoria, a la plenitud de vida en Cristo ( $c f . \mathrm{Rm}$ 5, 14; Jn 19,15).

Dios da sentido definitivo a toda experiencia religiosa. No podemos desvincular cualquier representación de la definición de lo sagrado, si esta no se articula en un lenguaje narrativo en el que se celebre con fuerza performativa la historia de encuentro entre el hombre y la creación, es decir, el Encuentro definitivo sacramental con Dios, para el que el hombre está naturalmente vocacionado. Esta formulación se debe instanciar en dos momentos. Un primero y primordial que, podemos referir como terminus a quo en el que es la experiencia vital del creyente la que sale al encuentro de la realidad misteriosa que se visibiliza en su interior. Es ahí donde brota la verdadera coyuntura sacramental que da entalle al homo sacer, entidad genuina de la constitución antropológica. ${ }^{4}$ Sólo después de esta asunción vital de lo sagrado escenificada en un realísimo encuentro con el Misterio, podremos acceder a la representación racional que dé acceso no exhaustivo, como terminus ad quem, al núcleo histórico-existencial de los sacramentos. La antropología teológica de GoNZÁLEZ FAUs (1987:110) da cuenta de esta

\footnotetext{
${ }^{4}$ Indispensable en esta visión complementaria resulta el enfa. ' estético de lo "sagrado", de claro empuje fenomenológico, desarrollado por AGAMBEN, $\cup$. en la magnífica trilogía Homo Sacer.
} 
perspectiva, en cierto modo invertida, de la mediación sacramental. ${ }^{5}$ En este sentido afirma:

La sacramentalidad la tienen las cosas cuando son miradas con los ojos de Dios. Por eso, la cercanía de Dios al hombre nunca supone un mayor apresamiento de Dios, pero sí se experimenta en esa transparencia de las cosas. [...] Trascendencia e inmanencia, distancia y cercanía, escondimiento y contacto, van manteniéndose así inseparablemente ligados en todos los desarrollos que aluden a la presencia de Dios en el mundo y a la relación del hombre con Él. ${ }^{6}$

Realidad interior que reinterpreta una realidad exterior de sentido, eso puede ser en palabras escuetas, lo que entendemos por sacramental. En concreto, para la fe cristiana esa realidad interior no es otra que la realidad de Dios trascendente. De hecho, ha de defenderse la autonomía e independencia epistemológica del pensamiento sacramental frente a otras formas de acceso al encuentro con el Misterio.

En síntesis, la dimensión sacramental no se puede fisionar de la capacidad simbólica que le es intrínseca a la capacidad natural de funcionar propia del conocimiento humano. Por otro lado, estas definiciones, siempre parciales, pueden dar la impresión de que lo "simbólico" y lo "sacramental" son una y la misma cosa. Aunque todo lo sacramental es marcadamente simbólico, no todo lo simbólico es sacramental en el sentido de que sea mediación de la presencia de lo Sagrado.

Es en este momento donde hemos de recuperar el carácter simbólico de lo sacramental. Dado que la manifestación de plusvalía existencial del hombre se circunscribe a la vivencia del símbolo sacramental como acceso al Misterio, hay que buscar la unidad de significados que nos conducen al Misterio en el perenne continuum materialidad-inmaterialidad de toda estructura simbólica. Este ejercicio nos conduce al corazón del misterio celebrado ritualmente que aúna todos los aspectos de la adhesión al Misterio, agrupando fides quae y fides qua o en términos menos marcados: fe, vida y celebración, convirtiendo, como indican los Padres, en realidad visible y presente una experiencia invisible y ausente.

\footnotetext{
${ }^{5}$ Cf. GonZÁlez Faus, J. I. (1987): Proyecto de hermano. Visión creyente del hombre. Sal Terrae: Santander.

${ }^{6}$ GonZÁlez FAus, J. I. op. cit., p. 110.
} 


\section{2.- Síntomas de una antropología simbólica anémica}

Un rápido diagnóstico descriptivo de lo que se ha dado en denominar "modernidad tardía" (J. Habermas) o "segunda modernidad" nos sitúa como espectadores privilegiados ante el espectáculo de una metamorfosis radical de la experiencia simbólica con repercusiones directas entroncadas en el dominio sacramental de los sujetos religiosos. Los últimos decenios han contemplado el advenimiento de un "giro iconoclasta" representado por una proliferación casi imperialista de lo icónico, que, en inversa relación proporcional, ha debilitado la presencia y desarrollo de la dimensión simbólica hasta conseguir su ofuscación hermenéutica o la aparición de una enconada pugna por la supervivencia del signo-símbolo. ${ }^{7}$ Del marchamo lógico-cientificista de la modernidad se han extraído muchos elementos próvidos para la concepción y desarrollo exacerbado de lo que en el artificial macrocosmos de la globalización se ha rebautizado como "era del progreso". Nadie debe poner en entredicho los logros científico-técnicos que en varios epifenómenos de la realidad moderna han acaecido para mejor salvaguarda y perpetuación del proclamado bienestar (obsérvese la diferencia no sólo terminológica implícita en otras lenguas que optan por hablar del 'bienser' [cf. ital. benessere]) del individuo moderno. Incluso en el ámbito religioso puede decirse que el motor ideológico tardomodernizador ha contribuido a una reorientación de ciertas actitudes consecuentemente tildadas de supercherías altisonantes en su aparato formal que, invirtiendo el orden natural, provocan un reduccionismo pueril e ingenuo en el comportamiento religioso de las personas.

Como si se tratase de un signo de los tiempos.este desarrollo de lo pararreligioso se ha acantonado en grupos cada vez más significativos en la dimensión pública (la única perceptible en el mundo del "imperativo de la imagen") contribuyendo a generar una contrarréplica a las tendencias dominantes que abogan por revitalizar la esencia radical.

Es en el lenguaje religioso donde mejor se perciben los síntomas de esta desecación simbólica de lo sacramental. Se está produciendo una emigración de la religiosidad practicada a la indiferencia, cifrada en el abandono paulatino de la práctica religiosa de la que los sacramentos constituyen el epicentro de referencia. Entendida la práctica religiosa como el cimacio de la experiencia simbólica del lenguaje religioso, la ausencia de

${ }^{7}$ Cf. MARDones. J. (2003): "El olvido del símbolo en la cultura de la imagen" en La vida del símbolo, Santander, pp. 17-32. 
práctica lógicamente desemboca sin solución de cambio en la indiferencia, en el cero absoluto de lo religioso, en la negación de las posibilidades de actualización de los aspectos trascendentales en el hombre. El clima religioso imperante da muchas pistas. Ningún analista contemporáneo duda de que estamos asistiendo a una metamorfosis de los comportamientos religiosos. Como tendremos ocasión de señalar con mayor profundidad (vid. infra), una de las causas no menores de este cambio se produce por un desencanto con las mediaciones prescritas institucionalmente que dejan poco paso a los particularismos identitarios de diversa procedencia social ante una oferta creciente de posibles alternativas funcionales al monocromo, yermo y repetitivo sacramentalismo ofrecido como inmutable por el peso de la tradición.

En este marco general, si la praxis sacramental se vislumbra y cobra cierta entidad, esta tiene su caldo de cultivo decididamente en el ámbito del símbolo. Este es signo fundante y comunicante que desborda y satura, como diría el propio Lévinas, la potencia comunicativa del significante biunívoco a un significado. Trasladado al ámbito de lo sacramental, esa "saturación sémica" es la que ha forjado una paulatina adhesión a la fe de Cristo a través de la cristalización de la performance sacramental. Es más, hasta hace un cuarto de siglo aproximadamente la vivencia tradicional de la fe solía ser certificada y medida por el exacto índice de participación de los fieles en el elemento litúrgico-ritual que los ahormaba y por el mantenimiento riguroso y taxativo del rito tradicional que imparte sensu stricto el ministro. No había espacio simbólico para el desarrollo de lo sacramental. Todo quedaba reducido a su mínima expresión ritual en el escenario litúrgico.

Si la reconstrucción de este retrato tiene algo de fidelidad al original, estamos en condiciones de postular las razones de nuestro parti pris, a saber, la pérdida de vigor en la interpretación (actio), desarrollo práctico (dispositio) y analogía (narratio) de los sacramentos en el mundo contemporáneo.

Es significativo que sea la voz de un psicólogo de la religión como VERGOTE la que se alce críticamente contra la situación del cristianismo católico de la postmodernidad. En su opinión, este ha experimentado un exceso hermenéutico como síntesis de un larvado proceso de "racionalización sobrenaturalista" que, como si se tratase de una fortaleza infranqueable barbechada en la Ilustración, continúa haciendo frente a los excesos falaces del "empirismo de la sospecha". Esta dialéctica apologética estaba marcada por los parámetros neoescolásticos que eliminaban toda potencialidad recreadora y provocadora del misterio de la fe vivida, sentida y experimentada. La crítica de este autor se sitúa en la vertiente eclesiocéntrica, en su opinión "se ha considerado de poco valor teológico la formación en 
el sentido humano del simbolismo, de la palabra, de la expresión afectiva y de la acción en comunidad. La iglesia está pagando hoy muy caro este racionalismo sobrenaturalista" 8 .

Con tal objeto, hemos adoptado una de las definiciones que de manera más unívoca puede sintetizar la actual coyuntura de la axiología antropológica ante la experiencia de lo simbólico. Esta ha sido cabalmente acuñada por MARDONES (2003) quien habla de una atroz y deshumanizadora "anemia simbólica" germinada en la paradoja del imperialismo de la imagen. Es la imagen trasladada fuera del marco de referencia o enfoque la que ha hecho que la codificación del lenguaje de la trascendencia se haya visto eclipsada por la hipercrítica racionalista afincada en el territorio del empirismo icónico formulado en el propósito, -permítaseme el símil coloquial- del "ver para creer" o del no menos manido "una imagen vale más que mil palabras". El resultado es evidente: los códigos suprasemióticos que figuran en la antesala fundante de toda mediación religiosa del espíritu se han desdibujado. Si, por recurrir a la brillante imagen de THEISSEN, el cristianismo, como toda religión histórica, es una auténtica "catedral semiótica", ahora buena parte de la belleza de ese templo se ha visto privatizada por la difusión mercantilista de la imagen del cristianismo, de modo que los perfiles que dibujaban la esencia crítica de ese movimiento se han ido paulatinamente difuminando hasta el extremo de hacer irreconocible, más allá de las operaciones de cosmética a las que se somete el rito sacramental que presenciamos cada vez con más frecuencia, la entraña simbólica del acto sacramental cristiano. Con todo, indagar sobre los desafectos de la capacidad simbólica nos conduce a un análisis más pormenorizado en el que el hombre asciende a la categoría de entidad sustentadora, generadora y comunicadora de realidades simbólicas. Por ello, para la atinada argumentación de esta esclerotización simbólica se antoja necesario un recorrido por los aspectos fundantes de la antropología humana que se define, al decir de CASSIRIER, como homo symbolicus, a saber, como hombre compulsivamente abierto a la esfera simbólica, que trasciende su propio alcance del horizonte conceptual en el que se ha instalado cómodamente en el último siglo y medio, bajo la forma de una fútil sombra conceptual sobre la que se constituye el balance entre su auto-contemplación y su carácter relacional con los otros. Tras el abordaje de los aspectos religiosos en los que se articula esa "simbolicidad" del hombre, habremos de abordar el locus o

${ }^{8}$ Vergote, A., (1998) "El sacramento de la penitencia y de la reconciliación", Selecciones de Teología, 145, 71-80 [72]. 
reino privilegiado de actuación del símbolo en el multifacético territorio religioso. Extraídas esas conclusiones, podremos finalmente establecer los patrones de lo simbólico que protagonizan el nuevo "giro simbólico".

\section{3.- El hombre, animal inquieto de desmesura}

La venerable tradición bíblica transmitida en el theologoumenon de la imago Dei (Gn 1,26: Sal 8; Sab 17,11) reserva un especial lugar para la presencia de Dios en la hechura corpórea del hombre. De acuerdo con esta teología, deudora de la ideología real de los pueblos del Oriente bíblico, los hombres deben actuar en el mundo como una especie de imagen viviente de Dios. Las imágenes divinas representan un cuerpo en el que la realidad divina se hace presente. En la imago Dei, se debe hablar más bien de una apoteosis que de la una verdadera teofanía. He aquí que entra en funcionamiento el principio sacramental, según el cual representar a Dios es configurar, en los límites de la sensorialidad humana, un símbolo del Misterio que no puede manifestarse por sí mismo, sino en forma humana de pies a cabeza. Por tanto, el hombre, amén de escrutador reflexivo y comunicador creativo de símbolos es una entidad sacralizada y sacramental, como la fe cristiana ha culminado en el cénit de la Encarnación.

No estaban nada desencaminados los hagiógrafos que compusieron el Sal 8, cuando dieron rienda suelta, engarzando al hombre con la teología de la creación, y se preguntaron haciendo eco a la pregunta milenaria cur homo? en contrapregunta retórica, tremenda y fascinante, aquello de "¿qué es el hombre para que te acuerdes de él? / el ser humano para darle poder" (Sal 8,6). Fascinante respuesta que es compatible con una visión no estrictamente controlada por la dimensión lógico-empírica. El hombre, creatura divina a su imagen y semejanza (Gn 1,26-27) se ha distanciado de la grandeza de su creación, se ha convertido en un ser menoscabado hasta ser concebido como "pasión inútil" que no deja de ser el contrapunto de la paradoja más destructiva de quien ha recibido el don de ser. La continua nota enajenante de lo simbólico ha dominado la interpretación del denominado "giro antropológico". Sin duda, esa actitud licantrópica del ser humano tiene una proyección directa en el ejercicio de la soberanía que le ha sido donada respecto a la creación. También en su "encuentro" con lo creado y las criaturas el hombre posmoderno adolece de perspectiva sacramental. Recordemos la prerrogativa designada por Dios en la Escritura: "henchid la tierra y sometedla, mandad en los peces del mar y en las aves de los cielos" (Gn 1,28). Estas palabras entregan la tierra al co- 
medido uso, no al abuso, del hombre, y hacen de Adán no el árbitro absoluto del gobierno de la tierra, sino el colaborador del Creador. Sublime vocación humana, si bien marcada por los estrictos límites que no pueden ser libérrimamente saltados. El corolario es diáfano: si el universo está frente al hombre como una primera revelación de Dios, un sacramento, cuyo primer reconocimiento nos compete a nosotros descifrar en clave reveladora, puede ser la inmejorable puerta de acceso al Misterio, de la Naturaleza. Según intuyó Juan Damasceno, adelantándose a la amplitud mística del кобноৎ como ambiente omnicomprensivo de la gravidez divina que asumiendo tantos riesgos propuso Teilhard de Chardin, la contemplación de la naturaleza es un dato indispensable para el conocimiento de Dios: lo espiritual puede aflorar teofánicamente en la materia por el hecho de que esta es portavoz de lo divino. ${ }^{9}$ En lo natural también halla asiento lo sacramental. Las realizaciones de este planteamiento (fases de la vida, momentos liminares de la existencia humana, etc.), pautadas en la vida del hombre, confieren un carácter de constante sacramentalidad a la vida humana.

La reflexión ante litteram de SAN Agustín (Confesiones X, 6) en un sublime ejercicio de introspección que coronada con la argumentación del origen divino del hombre como fruto del amor de Dios parece advertir la deriva exocéntrica en la que se ha visto aprisionado el individuo postmoderno en su incapacidad de reconocer los reflejos de los arquetipos divinos hipostatizados en su anatomía corpórea, dándole la apariencia de un objeto insensible, arrancado de su interioridad, retornado al vacío primigenio, en un estado de pre-creaturalidad que lo precipita con creciente celeridad a la desaparición de su propia connatural riqueza ontológica, personal y dialógica. ${ }^{10}$

A continuación, de manera sintética, trataremos de iluminar esa desmesura que es el hombre, haciendo un retrato robot de esa actitud, anti-teologal, que lo ha convertido en una entidad anti-analógica. ${ }^{11} \mathrm{El}$ retrato del

9 Cf.. JuAn Damasceno, De imaginibus oratio 1.16: PG 94, 1245a. P. TEILHARd DE CHARDIN es el mejor exponente de una "pan-simbolización" trascendental de la materia, incluso de la materia crística (punto omega) tan definidora de esta visión sacramental de la Creación. Vid. infra donde retomaremos algunas de estas ideas. Cf. a este respecto su célebre obra El corazón de la materia, Sal Terrae: Santander, 2002.

10 Interesante a este respecto, por saber integrar diferentes perspectivas que derivan fundamentalmente del pensamiento antropológico unidimensional de MARCuSE en una paleta de categorías borrosas de cristianos, es la obra de R. LATOURELLE (1984), El hombre y sus problemas a la luz de Cristo, Salamanca.

${ }^{11}$ Muchas de las ideas abordadas en ese panorama antropológico postmoderno están inspiradas en el original y comprometido ensayo de antropología trinitaria de Edoardo ScOGNAMIGLIO (2009): El rostro del hombre, Salamanca, pp. 45-109. 
ser humano puede ser esclarecedor para interpretar su alejamiento de las coordenadas de la "razón simbólica" avalada por el pedigree cultural que supone el haberse forjado en la época en la que tanto más cuantitativamente se ha avanzado en el conocimiento de "lo humano" cuanto cualitativamente más se ha difuminado el verdadero rostro humano. Así, HEIDEGGER señalará apodícticamente: "En ninguna época como en la nuestra el hombre ha llegado a ser tan problemático". ${ }^{12}$ Yo añadiría: en ninguna otra época el hombre ha dejado de ser tan conscientemente irresolutivo ante los problemas fundantes de su existencia. La siguiente propuesta de rasgos trata de completar esta visión de los hechos.

\subsection{EL DISEÑO ARTIFICIAL DE LA ANTROPOLOGÍA DARWINIANA}

En la presentación de este asunto vamos a proceder explicativamente por via negativa. Valga la contradictio in terminis: la racionalidad de la fe en la creación hoy por hoy es el postulado más plausible teoréticamente en términos de la teoría de la evolución. No cabe duda, después de siglo y medio de teoría de la evolución ha de reconocerse razonablemente que ninguna teoría científica puede responder y, mucho menos agotar, las respuestas a la pregunta sobre el sentido de la vida humana. ${ }^{13}$

En los últimos tiempos han surgido opiniones de especialistas procedentes de la bio-antropología que han proclamado un veredicto definitivo contra Darwin, hasta el punto de que, del mismo modo que sucedió con el darwinismo social décadas atrás, se han puesto en entredicho por "dogmáticos" el objetivo y la metodología de la "selección natural" de las especies tal como la propone Darwin. Uno de los defensores más altisonantes de esta nueva visión "desmontadora del darwinismo" es el biólogo español Máximo Sandín quien en buena parte de su obra aporta argumentos de peso sobre muchos aspectos de la teoría de la evolución de Darwin. ${ }^{14} \mathrm{Re}$ mitimos a los especialistas en un campo en el que no nos consideramos suficientemente informados para remitir a una información que trasciende los límites de este trabajo.

\footnotetext{
${ }^{12}$ Cf. M. Heidegger (1981): Kant y el problema de la metafísica, FCE: México.

${ }^{13}$ Cf. SANDÍn, M. (2008): Desmontando a Darwin, Ediciones UAM: Madrid.

${ }^{14} \mathrm{Si}$ bien algunos de sus argumentos pueden resultar revisables en algunos puntos controvertidos que descienden técnicamente al terreno de los datos científicos y cuyo alcance explicativo se nos escapa, sobre muchos de los aspectos de la teoría de la evolución de Darwin.
} 


\subsection{EL "TECNOHOMBRE"}

Entre los instrumentos y condiciones mediante los cuales es posible describir hoy la identidad del sujeto humano, no está solamente la mediación evolucionista, sino también la posición que localiza al hombre en el epicentro del bautizado como paradigma cibernético y de las tecnociencias (biotecnología, eugenética, ingeniería molecular, etc.). Esta sobredimensión de la autocomprensión de la persona en clave técnica supone la contraprestación de los constituyentes simbólico-espirituales que definen a la persona. Se ha producido una mutación en la valoración hipercientificista del ser humano. La técnica moderna incide, especialmente, sobre la praxis humana, sin que la fe, la cultura o la política sean capaces de controlar ni describir la situación. Como señala espléndidamente RuIz DE LA PeÑA (1991), ${ }^{15}$ al hablar de la transición sustentada en el dualismo alma-cuerpo a otra nueva en la que los formantes identitarios de lo humano son mentecuerpo. En este ámbito es lógico que, en ciertos extremos, se llegue a recuperar la idea nitzscheana de Übermensch "superhombre" que adquiere forma y fondo robóticos. En este clima se sitúa una nueva revisión crítica a la ciencia en la que aflora cierto determinismo de matriz biológico, que niega la libertad de la persona y reduce el sentido espiritual y trascedente de la vida, de su ser memoria Dei, ofreciéndonos solamente una interpretación de carácter espacial y matemático del tiempo. El imperativo lógicocientificista de la mensurabilidad recorre todos los goznes de la definición contemporánea de hombre. Esta es una de las aportaciones fundamentales de BERGSON, que supera en su personocentrismo toda oposición de contrarios. Esta visión del hombre ofrece su natural desembocadura en una especie de mecanicismo aberrante. El mundo es patrimonio de la acción técnica que ofrece resultados mayoritarios y más visibles a la vida humana de lo que las denominadas "ciencias del espíritu" pueden ofrecernos. Este paradigma reduccionista nos permite, como recuerda bien HEIDEGGER, estar sometidos abiertamente al cambio, a nuevas revoluciones y transformaciones que se han orillado en las costas del ejercicio de la técnica. El Dios que se propone como sustitutivo de este continuo marchamo cuya esencia consiste precisamente en eso, "en pasar" (Vorbeigang), es un Deus semper adveniens, muy distinto del Dios de Jesucristo. En esos casos, el hombre queda simplemente como centinela (Wächter) de la quietud silenciosa del último transitar divino. En palabras de HEIDEGGER la verdadera

${ }^{15}$ Ruiz de LA PEÑA, J.L. (1991): Nuevas antropologías: un reto a la teología, Salamanca. 
redención de este "tecnohombre" radica en evocar a la última respuesta de sentido, a la "pura necesidad de ser" que lo incite a la liberación de la técnica y del progreso siempre recursivo. Una recuperación de la esencia corpórea y encarnatoria debe sustentar la reconstrucción del hombre postmoderno a partir de los rescoldos y de las certezas axiológicas que siempre le han distinguido de todo lo demás en el mundo en su perenne encuentro entre naturaleza y cultura. Estas coordenadas nos permiten asistir al fin de un nuevo ciclo en la evolución axiológica del hombre. Tras el advenimiento del primer hombre (homo sapiens), marcado por una visión cósmica y cíclica de las relaciones temporales, se implantó el homo religiosus (sc. "religado") fruto de la concepción teleológica y escatológica bíblicas. Tras ellos, hemos llegado al tercer hombre, el evolucionado (homo faber), es decir, un hombre en continua expansión que apunta hacia el "punto omega" para construir su verdadera alcoba humana. Finalmente, nos hemos quedado inmovilizados ante el advenimiento del cuarto hombre, el rebautizado, hombre postmoderno que comienza a existir desde el momento en que a nuestra época ha sido caracterizada por la interdependencia mundial en la prefiguración de la "aldea global", neoliberal y capitalista, que adelante un retorno al caos primigenio del fin de los tiempos. El retrato del Adán de nuestros días es esencialmente un "ser problemático" pues las respuestas fundantes $\pi 0\llcorner\kappa \alpha \iota \pi 0 \theta \in \nu$; " $¿$ de dónde y adónde?" de nuestro devenir permanecen inevitablemente abiertas. Este "tecno-hombre" está siempre en lucha para mantenerse adherido al bien, por salvar su dignidad ética ante los otros y ante el mundo. Este cuarto hombre ha resuelto la dialéctica objeto-sujeto en favor de este último y se ha convertido en protagonista único de la historia que totalmente protagoniza. Es un individuo artífice de lo artificial. En un afán globalizador que puede dar la impresión de amalgama "confutada y falible" en palabras de POPPER, cataliza los demás modelos antropológicos que le han precedido, pero en desequilibradora síntesis. Este juego continuo de interferencias variadas quizás sea el síntoma prefigurador de la llegada de un quinto hombre de un Emmanuel crístico, "Cristo con nosotros", del nuevo Adán paulino. Esto supone, no simplemente rescatar la imago Dei tradicional, sino situarla en las cosas y a través de las cosas del mundo. Esto supone enfatizar la experiencia de Dios que posee cada hombre. Como el hombre es, en sí mismo, una experiencia "entusiasmada", una continua presencialización y personalización divina, se infiere diáfanamente que al construir la propia historia en diálogo con su tiempo, el hombre configure el misterio de Dios dentro de sí. Esta es la posición que de manera constante se insinúa en la obra de $\mathrm{ZU}$ BIRI. El hombre es una realidad absoluta, es algo fundado sobre la trans- 
cendencia de Dios en las cosas. De ahí se llega a la conclusión de que Dios es la experiencia del hombre.

Los filósofos de la "acción" han dado buena cuenta de los condicionantes de un mundo tan activo técnicamente de la modernidad. BLONDEL reconoce la vigencia del método de superación de la inmanencia en cualquier acción humana que tenga por objeto la superación del mero tecnicismo y extrinsecismo limitado por el corsé científico-técnico. Toda acción lleva aparejado un transcendentalismo en su ejecución. El mismo reflejo de la acción humana en el mundo demuestra que la voluntad del hombre, sea cual sea el objeto sobre el que se aplique, siempre tiene una apertura espiritual y trascendente que, mediante la intervención de la gracia divina, expande existencialmente la experiencia humana en diálogo con esa otra que busca un continuo "más allá" en el ser de las cosas. La supervaloración de la realidad técnica incide en proporción diametralmente inversa en la percepción de una humanidad simbólica.

\section{3. ¿EL HOMBRE CIBERNÉTICO COMO QUINTA MODALIDAD DE HOMBRE?}

Los analistas de la cultura contemporánea que proponen búsquedas asentadas en un humanismo cristiano (MOLTMANN, DE LUBAC o PANNENBERG por poner sólo unos ejemplos) cifran en la revolución biológica, informática y de las telecomunicaciones el escenario en el que se sitúan los avatares del hombre hodierno. De estas revoluciones la más decisiva es la que se juega en el terreno de lo que se conoce como "biotécnica". Es la que, desde la perspectiva religiosa, más puede incidir en los valores éticos de modo que el mundo de la ética de la ciencia es un inexcusable lugar de discusión para valorar el carácter simbólico del hombre. En este campo parece imperar una doble relación dialéctica: "todo se concede al uso de la técnica por el hombre" y "todo se niega al uso del hombre por la ciencia". Está claro que la ciencia no es antropológicamente neutral. El imperativo lógico-cientificista del modelo epistemológico vigente no sólo diluye progresivamente la capacidad evocadora del hombre, sino que presenta consecuencias y responsabilidades decisivas en el ordenamiento moral del ser humano. En este contexto nace el "hombre cibernético" como proyecto científico y ético que toma conciencia de que se halla en un momento de cambio histórico que le ha permitido entrar en los arcanos de la genética y de la bioingeniería. El investigador puede, mediante manipulaciones del ADN, conmutar el orden y la configuración natural del ser humano. Estamos a las puertas, por tanto, de un nuevo paradigma que no ha escapado al 
reino de la contraposición extrema ("síndrome de Frankestein"), que mecaniza una visión totalmente aberrante de todo lo procedente de la ciencia. Un nuevo "foso" se abre entre los verdaderos logros de la ciencia y de la tecnología y la conciencia que tiene la población media mundial sobre la naturaleza de esos avances. Esa falta de acceso a las verdaderas novedades científicas es un factor ejemplificador que denota la ausencia de permeabilidad de los avances científicos. Se habla ya de "transhumanismo", es decir, un nuevo movimiento tecnofilosófico que cree en la transformación de la raza humana en ciborg. El hombre-máquina se presenta como la realización de una humanidad superior, más poderosa y con más capacidades que la actual. Los ciborg notan progresos en la comunicación, en el conocimiento, es decir, creando máquinas más inteligentes que los seres humanos. Pero si retornamos a la valoración de la dimensión transobjetiva y translaticia de los impulsos experienciales de la realidad nos topamos de frente con un muro infranqueable: ¿qué sucede con la vivencia espiritual y afectiva del ciberhombre ${ }^{16}$ La tecnología, por mucho que prosperen y se extiendan sus obras técnicas, no puede dar una respuesta ni puede interpretar el misterio de la persona, el sentido último de la dignidad de la persona. En esta perspectiva es preferible quedarse con el viejo y débil hombre que todavía indaga impenitentemente por encontrar las huellas del misterio, de respuesta a las inquietudes del espíritu, de iniciar el viaje del alma.

\subsection{EL HOMBRE MÁGICO DEL SINCRETISMO CONTEMPORÁNEO}

El marcado subjetivismo cultural que caracteriza nuestro tiempo favorece la difusión de creencias vagas y sincretistas, por lo que cada uno elige de los diversos ámbitos religiosos o filosóficos aquellos elementos que considera más afines a su propia contextura vital. Al mismo tiempo, se produce una revitalización de los movimientos que proliferan en medio de un radicalismo itinerante que favorece el seguimiento de líderes carismáticos que prometen un intervencionismo indirecto promisorio de alivio físico, psíquico o moral y que se anuncian como puntos de referencia tranquilizadores. El triunfo de las fuerzas del mal, que se presenta como una aspiración que hay que alcanzar, en la saga protagonizada por el mago Harry

16 Sobre las relaciones hombre-máquina son interesantes las visiones de WARWICK, K. (1998) In the Mind of the Machina, Londres o KuRzweIL, R. (1999) The Age of Spiritual Machines, New Cork. 
Potter patentiza esta situación. ${ }^{17}$ Un psicologicismo sobredimensionado ha desvirtuado el entramado simbólico del hombre, exaltando la dimensión emotiva y un sentido difuso de angustia, propio de las situaciones existenciales críticas, inclinan hacia una religiosidad fuertemente emocional y mágica que buscan un éxtasis físico y psíquico. Este clima espiritual refunde una experiencia natural de la realidad que contempla con superstición el mundo circundante.

Hay diversas formas de proyección de la perspectiva mágica a través de prácticas mágicas que en el clima cultural postmoderno han ejercido su natural fetichismo a través de la adhesión supersticiosa a objetos. Algunas de estas características aparecen en los movimientos de la conocida como New Age. ${ }^{18}$

Estos movimientos se pueden relacionar con el prendimiento de una neopaganización de la realidad con paralelos sorprendentes de alcance transcultural similares a los que se sucedieron en el inicio del helenismo. Recuérdese el florecimiento sincrético que se produjo una vez que Alejandro Magno ex-

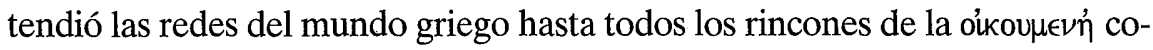
nocida. Aparecen nuevos retos en forma de astrología, cartomancia, horóscopos que evocan aquella simbología helenística que insertaba el destino

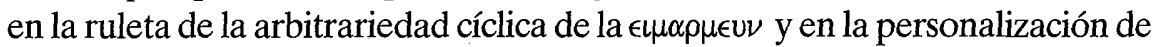
la diosa Fortuna como fundamento liminar del que depende la propia vida.

Este escenario mágico-supersticioso protagonista de la postmodernidad se amplifica en otras dimensiones en forma de mediaciones religiosas que pretenden conminar las fuerzas ocultas de un entorno perennemente negativo y hostil ante la debilidad del hombre. ${ }^{19}$ Existen también mediaciones con el "Más Allá". El ocultismo y el espiritismo extienden su mediación en formas diversas.

${ }^{17}$ En marzo de 2003 Joseph Ratzinger comparte las críticas realizadas por un sector de la crítica literaria alemana al contenido de Harry Potter detectando elementos de presencia del mal en el mundo en la que la mirada hacia Dios aparece totalmente soslayada.

${ }^{18}$ La Iglesia sintetiza bien sus doctrinas sobre la visión del hombre de los movimientos de Nueva Era y su incidencia como crítica de la ciencia y de la fe en el Consejo Pontificio de la Cultura - Consejo Pontifició para el diálogo interreligioso: Gesù Cristo portatore dell' acqua viva. Una riflessione cristiana sul «New Age».

${ }^{19}$ Somos muy conscientes de que el límite del uso del término postmoderno se ha convertido en un anacronismo poco esclarecedor. De hecho, los pensadores como VATTIMO que hablan del mito del "fin de la historia" que domina en el ideario postmoderno se han dado cuenta del fracaso de estas apocalípticas de nuevo cuño. Esto no es más que una simplificación, pero es claro que el pensamiento actual camina por otros derroteros más anclado a esperanzas de optimización histórica mucho más dialogantes con la experiencia vital, fraterna e interpelante con el mundo. Una buena síntesis sobre el alcance del postmodernismo se encuentra en varios trabajos de D. NATAL ÁlvarEz. 
Toda esta síntesis de los "lugares comunes" de la experiencia crítica de la antropología vigente no ha apagado la sensibilidad simbólica tradicional y reconfigurado un nuevo ideario de trascendencia que hunde sus raíces en la nueva prefiguración de la religiosidad actual de los "nuevos movimientos religiosos" (NMR). ${ }^{20}$ Lo más curioso es que este proceso hunde sus raíces en una reinterpretación de cierta simbología de las mediaciones cristianas pre-existentes que suponen la reactualización de ciertos mensajes revelados con validez histórica. Otros se inspiran, en este incesante proceso de proliferación supersticiosa, en las experiencias espirituales orientales, especialmente en tradiciones esotéricas y ocultistas. Este es el terreno de la magia. La magia, redimensionando el Absoluto o asumiendo la forma engañosa de su semblanza, pretende operar holísticamente con exigencias de dominio y de control absolutos. Este pensamiento mágico es la vertiente religiosa postmoderna confrontada con el fragmentador análisis merológico que actualiza el método científico. Pero, perplejamente, magia y religión están más próximas en su acceso a lo trascendente. El Misterio adquiere forma y sentido en el ámbito de la naturaleza y de la historia, riveras del hontanar numinoso. La magia navega, al contrario, por los meandros de la absoluta inmanencia falsificando sus mediaciones espurias que le conducen a falsos absolutos que trata de resituar en el Absoluto fundante. La magia acaba justificándose exclusivamente a sí mismo, por lo que, todo lo que gira en torno a esta falsa mediación del Misterio se convierte en un círculo cerrado que aborta los mecanismos naturales de acceso a la realidad trascendente. De hecho, si en relación a la ciencia, la magia se presenta como una degradación autogenerada, es decir, como una manipulación de las leyes de la naturaleza, contrapuesta a la religión, la magia se presenta, por su parte, como una instrumentalización del misterio divino. Se origina en el intento manipulador de sus usuarios de apropiarse e instrumentalizar el misterio divino. Como la propia marcha cultural actual demuestra, el recurso a la magia no queda reducido a fases de la historia en la que abunde un tipo de explicación pre-científica, sino que, lógicamente, también se encuentra en fases del desarrollo histórico en las que triunfa un acercamiento racional al conocimiento de la naturaleza. En cualquier caso, tanto la experiencia científico-filosófica como la religiosa se muestran a una

${ }^{20}$ Por Nuevos Movimientos Religiosos entendemos un conjunto de fenómenos que, aunque no exclusivos de nuestra época, han irrumpido en todas partes durante los últimos decenios, modificando la situación religiosa, los diagnósticos que se hacían de ello y los pronósticos sobre su evolución. Cf. MARTíN VELASCO, J. (1993): El malestar religioso en nuestra cultura 1993, pp. 53-78, Paulinas: Salamanca. 
apertura dinámica del hombre "transliminar" que queda abortada en la pseudo-simbología ensombrecedora del Misterio. En ambos itinerarios el límite no es la última palabra del Misterio, sino sólo un momento suyo provisional. Esto es especialmente patente en el cristianismo donde, a diferencia de otras tradiciones religiosas, sea la iniciativa de Dios al revelar el Misterio, sea el carácter particular intrahistórico que asume el Misterio como realización de un plan de creación y de salvación centrado en Cristo, garantizan que éste posea un sentido último y definitivo en cuyo discernimiento interviene decisiva y primariamente la apertura simbólica y vivencial de la realidad.

\subsection{HOMO OECONOMICUS}

La emancipación global de la actividad económica se ha convertido en el punto de referencia esencial no sólo para las decisiones tocantes a la ética. El individuo libre y egoísta del que habla A. SMITH ha proliferado en forma de unos pocos individuos instalados en el poder financiero a escala mundial que detentan el monopolio de las relaciones macroeconómicas. Esto ha contribuido a la configuración de una nueva propuesta de homo oeconomicus que ha sustituido por elevación latréutica de lo utilitario al simple homo sapiens ajeno al imperativo moral del economicismo. Este superávit representativo de lo económico tiene consecuencias deletéreas para ciertas antropologías clásicas. La economía se ha convertido en la medida de todas las cosas sobre la que se proyecta la sombra de un hombre crecido que vive en la superficie, víctima de la pura exterioridad utilitarista. En las relaciones dialécticas, que basamos en el Encuentro o en la interacción con el prójimo, el homo oeconomicus corre el riesgo de reducir a mero objeto a su interlocutor. Aunque el dominio lingüístico utiliza a la ligera el término económico, en realidad, la nota dominante abunda en lo crematístico, por utilizar la dualidad terminológica de Aristóteles. Nuestra época forja a hombres crematísticos, no a verdaderos ecónomos, es decir, a aquellos que saben utilizar los bienes como medios para satisfacer las necesidades concretas por medio de acciones encaminadas a la solidaridad y a la coparticipación. Una correcta interpretación de lo económico en el hombre debe ir asistida por una antropología que permita la prosperidad equilibrada de la humanidad. La propia dignidad de la persona sólo puede expresarse si se recurre a un verdadero ejercicio de los derechos fundamentales de la persona. También las tentaciones de esa hipertrofia crematística pueden hundir sus raíces en la inhabilitación simbólica de los 
individuos. Resulta muy difícil disipar el influjo de este pantótum económico casi diabólico para las expectativas de espesura de lo humano. La transformación de la sociedad moderna es una despiadada constatación de los valores auténticos, de la vulgaridad del poder y de la arrogancia de la vida que se sintetizan en un cúmulo de relaciones económicas que alejan al hombre de su propia esencia humana.

\subsection{UNA ANTROPOLOGÍA RELACIONAL $\epsilon \xi \alpha \nu \alpha \gamma \kappa \eta \varsigma$}

Consideramos que el mejor enfoque para realizar un análisis de un fenómeno religioso debe partir de una experiencia dialógica o relacional que vamos a definir como fenómeno del Encuentro con lo Absoluto. Los postulados del Neues Denken se basan en la importancia del diálogo, de la alteridad, de la experiencia interpersonal. ${ }^{21}$ Esta dialéctica imperante en el ámbito ontológico-existencial, también puede ser aplicable a otras dimensiones superiores del pensamiento, como la metafísico-trascendental. Trasladada esta visibilización dialéctica de la realidad, de los otros y del propio sujeto a la perspectiva del Encuentro definitivo con el Misterio, podemos señalar que es en el ámbito del reconocimiento del Misterio de Dios uno de los escenarios donde mejor se pueden percibir las mediaciones analógicosimbólicas que nos introducen en los aledaños de la experiencia de Dios. Encontrarse con el Otro significa trascenderse. Hay mil maneras de autotrascendencia "originadas por la existencia en el corazón del hombre de una impronta, huella, imagen, pondus, que suscitan la inquietud y ponen en movimiento el trascendimiento". ${ }^{22}$ Los hombres siempre han querido representarse el encuentro definitivo con el Misterio mediante el contacto inaprehensible con Dios, a través de la vía unitiva, según predica Pablo: “ya no vivo yo, es Cristo quien vive en mí". Este despojamiento del yo exige una utilización simbólica del lenguaje de la reciprocidad simbólica para experimentar hondamente un profundo sentimiento religioso. El conocimiento de la realidad humana se desestabiliza y se hace opaco si se

${ }^{21}$ La quintaesencia de este pensamiento que privilegia un giro hacia lo relacional y la sociabilidad como una experiencia primera por encima del propio pensamiento empírico se sitúa en el horizonte filosófico de un grupo de pensadores judíos que experimentaron la necesidad de un giro radical en la concepción de las relaciones interhumanas. Podemos destacar a representantes de varias generaciones de este pensamiento relacional: ROSENZWEIG, BUBER, MARCEL, EBNER o LÉVINAS comparten similares miras hermenéuticas. De especial interés para el asunto que nos ocupa resulta la obra de M. BuBER $\left(1995^{2}\right)$ Eclipse de Dios, FCE: México.

${ }^{22}$ Martín Velasco, J. (1995): La experiencia cristiana de Dios, Trotta: Madrid, pp. 28-29. 
circunscribe a relaciones de tipo sujeto-objeto. La sociedad contemporánea cobra sentido en la encrucijada de la relación entre sujetos por el lado de la categoría encuentro. Si este balance de raigambre relacional se contempla como necesario en la comprensión de la posición del hombre respecto al hombre verdadero, tanto más necesario su recurso será preciso, cuanto mayor ese encuentro se convierte en el Encuentro máximo con el Misterio que nos trasciende. Conscientes de que el interlocutor divino es inaccesible si se encastra en los límites de nuestro lenguaje inmanente, pues no podemos dirigirnos directamente al Absoluto: el arbitrio de un modo de hablar simbólico se convierte en el único medio de superar el apofatismo pueril que pretende acoger en forma absoluta ese cara a cara entre el tú humano y el yo divino. Siempre que nuestra capacidad de expresión proposicional se aplica referencialmente al Misterio, sin duda, estamos poniendo en juego nuestra capacidad de transcendimiento y nuestra búsqueda simbólica de los límites de nuestra creaturalidad. Ese escenario, como quedará descrito en las siguientes páginas, ha sido especialmente cultivado en el genuino espacio, vedado de trascendencia, de los sacramentos, tanto en su dimensión externa-significante del ritual (sacramentum credendi) como interna-evocadora de la vivencia especial que supone la adhesión a Jesucristo (sacramentum orandi). Así, la persona, en cuanto entidad sacramental individual de naturaleza relacional, cuanto más entre en contacto con los demás y con el mundo creado tanto más se abrirá el abismo de lo simbólico y lo sacramental para su percepción. El hombre está destinado a autocomprenderse en la medida de su capacidad de emancipación simbólica.

\subsection{SÍNTESIS: EL CAMINO DE LA ANTROPOLOGÍA SACRAMENTAL}

Partimos de la definición del hombre, contrastada desde mucho antes del dominio de los existencialismos personalistas, en calidad de homo symbolicus. El conocimiento simbólico atraviesa y promueve toda la vida humana, hasta el punto de que símbolo y conocimiento humanos son co-implicativos. El símbolo se fundamenta en una epifanía vital. Allá donde hay símbolo late la vida a raudales. La completa dimensión de la vida misma, incluido, por supuesto, su aspecto psíquico constituye el reino soberano del símbolo. De acuerdo con esa transversalidad vital, el ser dotado de mayor capacidad simbólica será precisamente el que gozará de mayor predisposición hacia lo simbólico. En este sentido se puede decir que el hombre tiene naturaleza simbólica en cuanto fagocitador y catalizador perenne de símbolos. La perspectiva analógica de la realidad tiene este sentido. El hombre, 
capacitado de símbolos, es capaz de agrupar, en virtud del principio de analogía de significados y significantes diversos con el fin de formular nuevos valores hipercaracterizados de función simbólica, es decir, recordando a Goethe, transfigurando lo concreto en abstracto. ${ }^{23}$ Por otra parte, cabe decir que el ámbito de aplicación de lo simbólico en el hombre sólo puede darse en la alteridad que supone la existencia de un receptor ajeno. La existencia de un receptor convierte la comunicación simbólica en signo efectivo del marchamo simbólico. Sin receptor no hay itinerario siquiera de conato de búsqueda hacia el Misterio. De hecho, el receptor último de la experiencia relacional es el hombre. Es condición de necesidad (cf. 2.6) que existe un "tú" que ocupa la otra orilla de lo simbólico con el fin de completar la singladura simbólica. Por tanto, la antropología simbólica o un simbolismo antropológico deben entenderse, por su coarticulación, como casi pleonasmos, cuando aluden a una realidad suprema. La fenomenología de las religiones (cf. MARTín VELASCO 2007) ha demostrado que el hombre expresa esa capacidad religiosa de relacionalidad con lo Trascendente a través de categorías religiosas que manifiestan esa dinámica connatural al individuo. Toda la realidad se difracta en lo "sagrado": objetos, lugares. Placer UGARTE (1999) es bien explícito al considerar la inexorabilidad del encuentro analógico entre relacionalidad y simbolismo humano en torno a la praxis sacramental contemporánea ideal: ${ }^{24}$

"Hoy se deben entender los sacramentos como encuentro, símbolos, expresión de la fe y celebración de la vida. Porque el hombre no es sólo un espectador en la celebración sacramental, sino que en esta debe existir una perfecta armonía entre el ser y la condición sacramental que se ofrece. El hombre es un símbolo viviente. Por su presencia física, corpórea es un símbolo viviente que expresa su intimidad, libertad y voluntad; sus sentimientos, y pensamientos que no se pueden entender a simple vista, sino por la mediación corpórea. Esto es ser simbólico. Es la constante en la relación humana".

Vemos que el punto de partida es la corporalidad. Esta es la que nos hace ser origo y depósito de evocaciones simbólicas. Por el cuerpo empieza todo a discurrir. Las nuevas tendencias de la corporeidad deben, en conse-

${ }^{23}$ Un enfoque psicológico muy esclarecedor de la virtualidad del símbolo lo encontramos en la obra de Gilbert DuRAND, antropólogo de influjos jungnianos interesado en esclarecer el influjo del inconsciente colectivo aplicado a la realidad del mito, la imagen y el propio símbolo. Alguna de sus obras de referencia son: La imaginación simbólica; Lo imaginario y De la mitocrítica al mito análisis.

${ }^{24}$ Placer Ugarte, F. (1999): Signos de los tiempos, signos sacramentales. Ediciones Paulinas: Madrid. 
cuencia, formar parte de la dimensión sacramental, siempre y cuando no hallan marchitado lo que de sagrado puede haber en el cuerpo como canal de expresión sacramental. La sacramentalidad se vale de todas las dimensiones antropológicas. Recogemos a continuación algunas de las caras de lo humano que se proyectan en el "prisma" sacramental. En este apartado exponemos ideas muy conectadas con los presupuestos de la teología de la liberación, especialmente con las ideas de JON SOBRINO:

a) Carácter personal, intersubjetivo y analógico: el hombre accede a la lucidez del conocimiento mediante la expresión personal y mistagógica con el Misterio. No es el camino proposicional, ni la vía positiva, negativa o eminentiae las que nos permiten acceder más íntimamente a la fuerza recreadora de lo sagrado, sino, más bien una adhesión consciente de alcanzarlo en la recreación sacramental que nos ofrece la vida. Este encuentro personal que postula el conocimiento de Dios se ha de regir por la puesta en práctica de los mecanismos analógicos de aproximación a la entidad divina. Todo conocimiento y lenguaje de Dios ha de ser relativizado y analógico en esencia. En su aproximación analógica el hombre se adentra en Dios, a partir de los seres creados: per visibilia ad invisibilia. Esta misma hermenéutica analógica que rige las relaciones con el Absoluto puede servir de horma, aplicada a la Iglesia de Cristo y a sus sacramentos. Al menos desde la tradición tomista ( $c f$. Sum. Th. III, 60, 3), no olvidemos que los sacramentos significant, quod efficiunt ex opere operato. Esta eficacia privilegia el desvelamiento que, por graciosa intervención divina, favorece el descubrimiento de la presencia de Dios ya presente en las

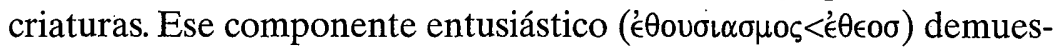
tra que la analogía se asienta en la base del simbolismo natural y de la economía sacramental en la Iglesia. ${ }^{25}$

b) Cosmológica: Sin cometer los excesos "panteístas" de las cosmovisiones holísticas que pretenden ver un todo sagrado en la realidad natural que neutraliza el necesario hiato entre Creador y criatura (Gn 1,26) que exhalan las tradiciones de raigambre abrahámico-bíblica, la dimensión sacramental abarca todo el orden creado. Una religión revelada en la historia y desarrollada en una economía de

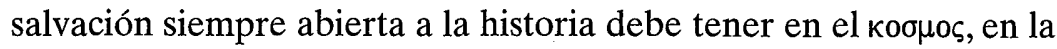
naturaleza y en el mundo su lugar natural de sacramentalidad. Como

25 Borobio, D. (2008): Sacramentos y creación, Salamanca. 
Boff nos alerta "el mundo es el gran sacramento de Dios. Cuando las cosas comienzan a hablar y el hombre escucha sus voces, entonces emerge el edificio sacramental". ${ }^{26}$ Otro lugar de referencia, bien testimoniado en la imagen bíblica del "resto de Israel", es el pobre. Este es un lugar teológico preferente en la cosmovisión sacramental contemporánea, lo cual supone un revivificación de la fe en el significado de la cruz que adquiere fuerza celebrativa plena en la Eucaristía asimilando ese memorial supremo del gran acontecimiento vertebrador del mundo abierto a todos los fieles sin condición. ${ }^{27}$

c) Economía de salvación: El plan de Dios se vertebra en la historia. El Padre actúa en la historia de salvación por medio de su hijo en la Pascua y por medio del Espíritu Santo en la Iglesia. Asimismo, el sacramento se actualiza como signo de los tiempos. El gran reto de la acción cristiana en el mundo supone descubrir desde la fe una apertura constante a esos signos, hacerlos significativos a través de su evocación simbólica, y, en ese proceso de sacramentalización, lograr transformarlos en historia de salvación particular y universal. El encauce soteriológico es clave en la interpretación cristiana. La historia se reinterpreta magistralmente a sí misma en un proceso sin parangón de relectura del pasado. Nuestro hic et nunc adquiere nuevos bríos salvíficos mediante su sacramentalización. Siempre estamos abiertos a realizar una relectura del presente abierta al futuro. Toda la vida humana puede ofrecer, por tanto, una perspectiva de salvación definitiva o, en su suprema negación, de desnortamiento y perdición. Sacramentar las vivencias las confiere historicidad, porque en la salvación culminan unitariamente los esfuerzos por vivir una vida sacramental.

\subsection{DE LA ANTROPOLOGÍA A LA ECLESIOLOGÍA SACRAMENTAL (PASANDO POR} LA PNEUMATOLOGÍA)

De la articulación de estas tres dimensiones se deduce un panorama clarificador. No hay que alejarse más allá del hombre para encontrar una

\footnotetext{
${ }^{26}$ Boff, L. (1977): Los sacramentos de la vida, Sal Terrae: Santander.

${ }^{27}$ La teología de la sacramentalidad primordial de los pobres está bien desarrollada en PIKAZA, X. (1981): Hermanos de Jesús y servidores de los más pequeños, Santander o SoBRINO, J. (1981) Los pobres, lugar teológico de la eclesiología, Sal Terrae: Santander. Cf. también GoNZÁleZ FAUS, L. (1984): "El problema de los pobres como lugar teológico", Revista Latinoamericana de Teología I, pp. 285-308.
} 
coyuntura vital sacramental. En la misma estructura antropológica se encuentra el fundamento de la dimensión sacramental de la vida y de los sacramentos. De la propia interioridad del hombre emana todo el potencial sacramental. Su existencia es puramente sacramental y toda ella ha de definirse como endógena, surgida dentro. Por lo tanto, a diferencia de la gracia exógena recibida, el hombre es el agente-creador de las dimensiones, profundidad y formación de su particular conformación sacramental. En ese sentido, desde una pura categorización lingüística, hay que reconocer que el sacramento es un modus vivendi et agendi, un modo de vida activa que nos permite la transformación ulterior en sacramento de cualquier realidad. Acudiendo al símil gramatical, el núcleo sacramental presenta un actor que deliberadamente genera una dimensión psico-cognitiva y analógica que le es connaturalmente propia, que tiene la posibilidad de portar sentido para los demás, a través de unos mecanismos de alteridad cultural, social y ritualmente bien pautadas (receptores) recurriendo a una manera universalmente válida de pensamiento en virtud del cual se presenta en inmejorables condiciones ante el Encuentro revelador con el Misterio. La perspectiva simbólico-sacramental como la podemos designar sintéticamente, permite fundirse en el mundo divino como mediación para transformar su entorno y dotarle de una plusvalía semántica de la que antes no gozaba. El mundo, las cosas, la vida ya no son unívocos. Con la perspectiva sacramental han adquirido carta de ciudadanía sacramental, alojándola en la Realidad, una muy reconocible Civitas Dei de las cosas creadas con virtualidad sacramental. ${ }^{28}$ Es en ese ordenamiento en el que hay que resituar la posición de los sacramentos. La antropología existencial de base debe estar bien comunicada con la oferta sacramental, que celebrada en la liturgia, y construida sobre la cabeza del Cuerpo de Cristo que le ofrece con libertad la Iglesia. El carácter plural, celebrativo y cristocéntrico debe dominar a la mera remembranza, muchas veces viciada por excesos de automatismos, de la praxis de la comunidad apostólica en la vivencia de la ex-

${ }^{28}$ La alusión al título de la obra de San Agustín no es una concesión gratuita. En los diversos escritos en los que el Obispo de Hipona, especialmente en el De Magistro y en De doctrina christiana aporta, dentro de su exposición de pretensiones sistemáticas, una definición polisémica del término sacramentum aplicado a órdenes de la realidad simbólico-real muy diversos que se van desde el plano epistemológico, teológico y ritual-práctico. Todo visibile verbum da lugar a un nuevo "sacramento" para Agustín. Esa plrralidad epifenomenológica de la realidad sacramental es un buen precedente magisterial pai ecuperar el carácter plural y vivificador de los sacramentos. Este proceso llega a su culmen en la afirmación agustiniana de que Cristo es sacramento. 
periencia de la Pascua y de la institución de los sacramentos. Es Cristo, sacramento total, $\alpha \rho \chi \eta \mu \nu \sigma \tau \epsilon \rho\llcorner o v$, quien a través de sus signos transformadores logró actualizar la presencia entre nosotros del Reino y a través de la experiencia pascual de la Resurrección los promovió hasta alentar cada gesto, cada símbolo de la órbita sacramental como si efectivamente fuese elaborado por la presencia activa del mismo Cristo. La misión en la reinterpretación sacramental que la Iglesia debe seguir es la del total compromiso. En fidelidad al origen pascual de los sacramentos, está destinada a arbitrar los mecanismos de necesaria reedificación de los sacramentos en la historia de cada momento. Su papel integrador y globalizador debe huir de toda imposición y mera "expedición" litúrgica, mediaciones que, como hemos analizado, han quebrado hace varias generaciones por ser opacas a las necesidades de recreación de lo "Infinito", si el objetivo es que lo simbólico irradie entre las generaciones cristianas, abiertas, de ese modo, con mayor consistencia y densidad al universo simbólico de lo sacramental.

Para colmar esta necesidad interpretativa tal vez sea necesario retomar el dato tradicional de Sto. Tomás de Aquino que reelabora la formulación más antigua de Hugo de San Víctor para quien "existen ciertos sacramentos (sc. no todos) en los que consiste y principalmente se recibe la salvación [...] como el agua del bautismo y la recepción del cuerpo y la sangre de Cristo". ${ }^{29}$ Las palabras de Sto. Tomás son claras. Existe una incorporación de lo sacramental en el propio cuerpo de Jesús. Este es un momento de institución sacramental que nos traslada a un ámbito evocador de referencias marcadamente pascuales. Las palabras de Sto. Tomás son claras al respecto y reconocen que los sacramentos por los que la Iglesia se constituye habían sido prefigurados por el agua (bautismo) y la sangre (eucaristía), es decir, los sacramentos mayores o principales, que brotaron del costado de Cristo en la cruz:

In cuius signum de latere Christi pendentis in cruce fluxerunt aqua et sanguis, quorum unum pertinet ad baptismum, alium ad Eucharistiam, quae sunt potissima sacramenta ${ }^{30}$.

${ }^{29}$ SAN Víctor, H. De sacramentis, pars I, cap. 9, c. 7 (PL 176,327 A).

${ }^{30} \mathrm{Sum}$. Theol. III, q. 62, a.5. Esta tradición teológica acarrearía en el Concilio de Trento controversias doctrinales condenatorias contra la validez homogénea de todos los sacramentos. En este momento, como indica Y. CONGAR (1988), adquiere curso legal la doctrina de la principalidad de los sacramentos del Bautismo y la Eucaristía. Lógicamente, por razones de espacio este asunto no va a ser tratado adecuadamente en nuestro trabajo, aunque también adquiera, como hemos comentado de soslayo, una perspectiva antropológica. 
La experiencia apostólica de los primeros seguidores de Jesús nos deja bien informados de que fue la dimensión de los acontecimientos pascuales tan grande que provocó una disonancia cognitiva o impacto afectivo que desde sus coetáneos ha llegado hasta nosotros. Sin duda, ese costado de Cristo del que emana la sangre, germen de una entrega carismática singular, es el mejor candidato para servir como epicentro semántico para construir el andamiaje simbólico de la sacramentalidad. El cristianismo tiene a su alcance el bagaje de la Tradición. El enfoque necesariamente enraizado en Cristo debe asumirse como significado radical sobre el que construir el ejemplo de la tradición. La tradición nos ofrece un caudal casi inagotable de hermenéuticas de lo simbólico que nos pueden auxiliar en esa tarea. Esa tradición, no obstante, debe ser conducente, a través de los indicios objetivos que indica el ambiente socio-cultural (signos de los tiempos) dictado por la antropología contemporánea, a la culminación crística en la vida creyente. Fijando el centro de nuestra experiencia simbólica en lo sacramental, podemos decir que todo se puede transformar en sacramento en cuanto indagamos en la realidad por el tamiz simbólico. La realidad se percibe simbólicamente, en la medida en que el hombre es un ser existencialmente sacramental.

En una perspectiva eclesiológica más amplia, cabe decir que se ha de buscar una correspondencia equilibrada y fundamental que sirva como marca de sentido entre las necesidades profundizadoras del hombre (sacramentología antropológica o baja) y lo que se le ofrece desde arriba (ritos sacramentales). El encuentro de estas dos dimensiones, tantas veces alejadas entre sí, puede ser la tabla de salvación de la vida simbólica.

\section{4.- Indicios de debilitación simbólica en la práctica sacramental contem- poránea}

El mundo religioso no se parapeta ajeno a esas circunstancias que destila la realidad, sino que contempla privilegiadamente desde su atalaya semiótica cómo esta sintomatología mórbida de lo simbólico se ha contagiado en su componente más definitorio y central, es decir, en la esfera semiótica de su ser. Es un fenómeno de ósmosis el que ha arrumbado la presencia simbólica de los sacramentos. Cualquier examen objetivo que se aplique a la presencia de la entidad simbólica en la dinámica de la fe cristiana de las personas observará que este se ve afectado de una flagrante pérdida de vigor, de vigencia e, incluso, de inteligibilidad en la vida del creyente. Esta morbilidad de 
lo estrictamente vivencial, reconocible en cualquier religión histórica, es especialmente palmaria en el "lugar teológico" en el que se encarna con mayor explicitud la genuina entraña cristiana: en la praxis sacramental. ${ }^{31}$

Se han enumerado numerosas causas que justifican esta pérdida de referencias simbólicas que afectan a la realidad sacramental contemporánea. ${ }^{32}$ Son el resultado de un cúmulo de epifenómenos que han dado lugar a la actual crisis de las mediaciones, especialmente notable en la disfunción sacramental perceptible, que han dejado de ser simbólicamente representativas. Siguiendo a MARDONES (2003), MARTín Velasco (1990) y BoroBIO (2012) podemos llegar a reconocer un alejamiento de la realidad cultural que se explica, en una perspectiva mayor, en la ruptura de los códigos que vehicula la experiencia de la fe del creyente y aquellos otros que son característicos de la cultura moderna. Así lo certifica Pablo VI en Evangelii Nuntiandi en su referencia al occidentalismo etnocéntrico y las nuevas formas de vida urbanita y desestabilizada en las que se dinamiza lo que llamamos mundo moderno.

La dialéctica que supone todo ejercicio de Encuentro personal muchas veces se frustra en el autorreconocimiento ególatra (hacia uno mismo) o idólatra (hacia una representación distorsionada de Dios). Este enfoque genera un símbolo falseado que no asume la verdadera realidad del Otro. La trascendencia de la realidad objetivable a la que alude este pseudo-símbolo se queda en la pura inmanencia, y el Misterio de Dios en pura referencia lingüística y funcional para mí y para nosotros, vacía de sentido. Se cercena, de ese modo, toda la potencialidad de una Alteridad con mayúsculas. La fuerza centrípeta del símbolo se ve entrecortada por la oposición centrífuga de la inmanencia que siempre se encierra en sí misma. El hombre acaba coartado en su ensimismamiento. Esos NMR a los que hemos aludido antes constituyen formas "puramente inmanentes" de tonos bañados en una espiritualidad laica. Se abastecen del lenguaje religioso, porque este es el único recurso a la explotación simbólica de la realidad que tratan de aprehender como camino iniciático a la Verdad. Este paradigma religioso liquida la significatividad del símbolo, lo quiebra y lo reduce a la convención del momento, lo tiñe de mera externalidad ritualista y lo simplifica

${ }^{31}$ Cf. RATZINGER, J. (1999): ¿Cuál es la verdad del cristianismo?, conferencia impartida en La Sorbona el 27 de noviembre de 1999.

${ }^{32}$ En este apartado ha sido de gran ayuda la consulta del trabajo de investigación inédito "Hacia la recuperación de la dimensión sacramental en la praxis pastoral" de S. FERNÁNDEZ alojado en la página web: http://www.monografias.com/trabajos16/dimension-sacramental/dimension-sacramental.shtml. 
en la horma lingüística del usuario. Esta descripción encaja perfectamente con la tendencia anémica de la praxis sacramental. El lenguaje religioso sigue siendo real, pero su capacidad vivificadora se ha encapsulado en un subjetivismo radical que no es ajeno al cristianismo. La ortodoxia, casi dogmatizada, del pensamiento relativista del anything goes "todo vale" en la que se procede a una exégesis del cristianismo subjetiva, al margen de toda teología e inspiración bíblica, actúa como si el símbolo no existiera. ${ }^{33}$

\subsection{LA FALTA DE COMPRENSIÓN DEL LENGUAJE RITUAL-SACRAMENTAL CRIS- TIANO}

Toda expresión religiosa es fundamentalmente simbólica y, si no es así, no se puede acceder a ella. Los datos procedentes de la fenomenología de la religión nos tienen bien informados a este respecto. El mito, los ritos y los actos de culto configuran y determinan la vivencia simbólica de la experiencia religiosa de los homines religiosi. ${ }^{34} \mathrm{En}$ su transferencia cristiana, los sacramentos ocupan el lugar fundamental de la expresión cristiana. Es precisamente en ellos donde se aglutinan toda la batería de sentidos que trasluce el simbolismo cristianismo. En ellos y sólo en ellos cobran vida, ex opere operato, los canales de acceso interpersonal. Como afirma CAILLOIS, es el rito el contrapunto activo al languidecimiento impelido por los excesos de la logosfera a la que asiste la palabra. El rito, por tanto, es un catalizador de las innúmeras procedencias y superposiciones histórico-sociales que terminan por configurar el universo religioso de una tradición religiosa. No es el lugar para analizar las vicisitudes históricas que han diseñado el universo simbólico del cristianismo, pero sí que es central en nuestro cometido valorar la crisis de la religión y, especialmente, de la sacramentalidad, a partir de la exigencia de unos planteamientos firmes de la "vida sacramental" cristiana como expresión de su dimensión cultual y dramático-simbólica de la religiosidad, conscientes de que este esfuerzo reflexivo nos ha de conducir a una revitalización de los sacramentos en cuanto ritos simbólicos que ofrecen respuestas claras y creativas que nos permitan abordar globalmente el sentido simbólico de lo que BOROBIO, haciéndose eco de

${ }^{33}$ Cf. VAlAdier, P. (2001): Un cristianismo de futuro, pp. 145-12.

${ }^{34}$ Sigue siendo una referencia inexcusable el manual sobre la materia de MARTín VELASCO, J. (2003): Fenomenología de la Religión, Trotta: Madrid, las pp. 123-186 están especialmente dedicadas a la cuestión de la definición de las mediaciones dentro de los lenguajes simbólicos. 
una larga tradición, ha dado en denominar "analogía sacramental". Pero antes de proponer una respuesta que abrace paralelamente tanto la dimensión teológico-filosófica (expresión dogmática) como existencial (expresión pastoral y vivencia sacramental cristiana) es momento de repasar las causas que han conducido a este desencantamiento personal y simbólico en la práctica sacramental cristiana. Algunas de las tendencias observadas obedecen más bien a prácticas que hunden sus raíces en la entraña sociológica, en su interpelación con la cultura contemporánea, mientras que otras, emergentes de esta casuística externa, se ven reflejadas en los continuos esfuerzos por reformular los lindes de la teología sacramental:

a) Esclerotización formulista y rubricista de la práctica sacramental derivada del antiguo predominio socio-cultural del cristianismo.

b) Acartonamiento ritualista de muchos de los símbolos y acciones sacramentales que han dejado de ser significativas para las nuevas generaciones y han provocado una invisibilización del rito.

c) Progresiva anemia simbólica generalizada en toda dimensión religiosa que, al verse desasistida en su apertura simbólica, busca refugio en las estructuras que crean subterfugios en forma de pseudo-mediaciones de tipo secular destinadas a descubrir un re-encantamiento de una sociedad desnortada de sentido.

d) Reinterpretación teológica de algunos puntos controvertidos de la teología sacramental.

Analizaremos detenidamente algunos de estos sentidos:

\subsection{EXCESO DE FORMALISMO E IDENTIFICACIÓN METAFÍSICA DEL RITUAL}

En este panorama general dominado por la incertidumbre simbólica de los sacramentos no se ha quedado al margen de esa vacuidad significativa la performance ritual consuetudinaria como un acto irreconocible en su exterioridad y baldío en su efectiva transmisión comunicativa de sentido. Esto es especialmente visible en el sacramento cenital de la entraña, en la Eucaristía que rememora el sacrificio propiciatorio de Cristo que celebramos en la Santa Misa. Asistimos a un descrédito generalizado de la vivencia sacramental y a un alejamiento no sólo de la percepción carismática de la vivencia cristiana, sino de la propia participación en un acto comunitario de escasa relevancia en la vida del fiel hodierno. Al fallar o debilitarse los mecanismos naturales de transmisión y mediación que conducen al Misterio, es decir, al faltar el motor de la adhesión a la fe, los sacramentos están 
condenados a la descomposición. Los datos son esclarecedores al respecto. La práctica religiosa, entendida, como suele hacerse, como práctica sacramental, especialmente en el sacramento de la Eucaristía, ha descendido en los últimos 25 años hasta cifras tan significativas como las que arrojan los datos estadísticos que cifran que menos de uno de cada cuatro jóvenes entre 18 y 34 años se declara religioso y practicante. ${ }^{35}$ En resumen, puede decirse que tanto menor es la referencia significativa de un sacramento, cuanto mayor es el verbalismo excesivo propio de nuestras celebraciones. Perspicua es la situación de la Eucaristía, sacramento de referencia central en el ámbito del ritualismo cristiano. La falta de respuestas procedentes de las nuevas agrupaciones religiosas favorece un pluralismo celebrativo y una falta de normatividad. Sin embargo, ese pluralismo en el desarrollo de una vivencia sacramental de las más diversas tendencias suele incurrir en un aberrante reduccionismo que asalta y derriba a las primeras de cambio la clave simbólica inspiradora de la performatividad sacramental. ${ }^{36}$ En la variada paleta de tendencias celebrativas que zozobran ante esta falta de sentido último de la celebración de la Última Cena del Señor, asistimos a un movimiento pendular que oscila entre los que intentan infundir un artificial énfasis en generar sensaciones y los que tratan de producir un mayor intimismo entre los que participan. En ninguno de los dos casos se fomenta una vivencia auténtica, comprometida y encarnada del Resucitado. Esta formalización por exceso desciende al nivel del epifenómeno. La propia práctica está desencarnada. Los elementos simbólicos se amontonan en muchas celebraciones como una acumulación impenetrable de elementos (agua, óleos, bendiciones, oraciones verbales, silencios, etc.), presentados de manera abigarrada, copulativa y difusa que no presentan una unidad intrínseca vital. El grupo reunido en torno al presbiterio aparece, por otra

${ }^{35}$ Martín Velasco, J: (1994): "Situación socio-cultural y crisis sacramental”, Phase 34,171 . Estos datos se refieren a los sondeos sobre la situación de la población activa y declaradamente religiosa en España a comienzos de los noventa. Hoy día ha de reconocerse que el incremento secularizador y el alejamiento de la fe y de la consecuente práctica sacramental se ha amplificado notablemente, especialmente en la franja generacional de menor edad.

${ }^{36}$ Nótense, por ejemplo, las recientes reticencias que se han interpuesto al movimiento religioso de evangelización (itinerario de formación católica) del Camino Neocatecumenal cuyas celebraciones litúrgicas están siendo revisadas por la Congregación para la Doctrina de la Fe por su deliberado marginamiento de la praxis litúrgica del magisterio eclesiástico. Se sabe que hay una búsqueda de cuño judaizante que se percibe en el reforzamiento de una eucaristía marginal, celebrada en locales independientes y segregados el sábado, por parte de los miembros de este grupo, amén de otras prácticas menores que se apartan deliberadamente de la normativa litúrgica al uso. 
parte, desconectado de todo ese aparato simbólico que, sin ser interpelado vitalmente, adolece de toda funcionalidad evidente. Los participantes, los símbolos y el sacerdote aparecen disgregados como disiecta membra, corpúsculos independientes, que agrupan elementos vagamente vinculados por una experiencia cristiana común. La lex orandi no da lugar a la lex credendi.

Como causa eficiente de todos estos elementos podría decirse que se observa un exceso de motivación verbal en todas las manifestaciones celebrativas. Lo lógico-discursivo se lleva la parte del león, adormeciendo muchas veces elementos visuales (oposición y contraste entre luz y oscuridad, tan viva en las visiones ortodoxas, la analogía sensorial que descansa en la variedad de colores asociados a los ciclos litúrgicos, etc.) lo paraverbal y corporal, mientras que lo estrictamente simbólico pasa a un muy relegado segundo plano en el que caben pocas posibilidades de acceso real al intimismo del verdadero encuentro con el Misterio.

En términos más amplios, asistimos a un predominio filosófico de la definición de los sacramentos. Se ha hecho una especie de metafísica del signo. Este proceso de progresiva filosofización es patente tanto en la historia de la teología en general como del dogma en particular. Y la teología sacramental no es sino una evidente muestra de ello. Este proceso, natural en otros períodos en los que el ambiente apologético exigía la creación de un discurso alternativo de fuerte base filosófica, sin embargo, ha favorecido que el pensamiento cristiano incurra en un flagrante reduccionismo del dato de fe a costa de un incremento especulativo del acontecimiento salvífico. En muchas ocasiones, la teología católica, recordando a VON BALTHASAR, ha abandonado el reclinatorio y ha hecho del gabinete filosófico su sancta sanctorum. Hemos pasado de una muy apostólica praxis de seguimiento doctrinal a disquisiciones intelectuales que poco o nada tienen que ver con la vivencia del Reino de Dios. Esta efervescencia que se diluye en el dato positivo, hermana de las tendencias antropológicas antedichas, ha desencadenado un vaciamiento del rito nada comunicativo para la vida del hombre contemporáneo. El rito, ahora vaciado de significado, queda ahíto de significante ritualista. El que asiste a este tipo de prácticas rituales necesita ya de una pedagogía artificial, que asfixia toda libertad y expansión creativas en el individuo religioso. La mediación se ha quebrado y la fuerza vital siempre renovadora de los antiguos signos en el sacramento de la Eucaristía resulta palmaria en su mismo anuncio: "en verdad os digo, si no coméis la carne del Hijo del Hombre y no bebéis su sangre, no tenéis vida en vosotros" (Jn 6, 52-53), o, sobre todo, en la novedad que supone una revaloración de la Pascua cuyo contenido y misterio será la muerte y resurrección del Señor, como muestran los relatos sinópticos relativos a la 
institución de la Eucaristía (Lc 22, 7-20; cf. Mt 26,17-29; Mc 14, 12-25). De esta densidad crística de los orígenes, se ha ido generando una conciencia de cosificación en la acción sacramental destinada a perpetuarse en su aspecto fósil o a extinguirse sin solución de continuidad en el crítico marco de la ruptura de las mediaciones religiosas imperante.

Pero los resultados de esta fosilización no sólo obedecen a causas externas del entorno, sino que los propios agentes de pastoral sacramental y el ritmo marcado por la práctica eclesial común, estancada hasta no hace demasiado tiempo en un predominio socio-cultural indiscutible, también contribuyen a ser una razón inequívoca de este proceso. Uno de los rasgos de la institucionalización, sin duda, es la fijación de un esquema doctrinal unitario y con tendencia al fijismo y a la validez universal. En tiempos de dominio y preponderancia institucional, este cuerpo admite pocas dudas y desajustes, lo que se traduce, por vía negativa, en un cierto inmovilismo en las prácticas rituales que no purifican su interrelación con el medio ni renuevan su lenguaje simbólico. Los sacramentos cristianos y, especialmente la Eucaristía como su modelo prototípico, se han quedado anclados en un aparato formal poco o nada representativos ante el pluralismo religioso y el creciente despunte secularizador que llevamos observando tanto tiempo. Una readaptación compleja del mensaje crístico, en el sentido de que, como sucede en los orígenes israelitas de nuestra fe, los signos de la Alianza se actualizan y revitalizan, debe ser el camino a seguir para instar al renacimiento central cristiano, origen y plasmación pascual, del acontecimiento totalizador cristiano. El principio sacramental actualiza la presencia de Dios en los acontecimientos históricos, aprehendidos por los sentidos. El Éxodo, más allá de la huida de un grupo de esclavos, evoca la voluntad de Dios por la justicia y la libertad. Es un sacramento que simboliza la liberación del pueblo elegido de su situación de esclavitud. Sin abandonar esta dimensión sacramental, en el NT el "nuevo Israel" es la Iglesia y el lugar de la presencia de Dios es Cristo. Avanzando más, esta presencia de Cristo tiene fundamentalmente dos lugares sacramentales: la Iglesia como corporeización simbólica del cuerpo de Cristo (SC 7a) y, en un lenguaje bien madurado por la teología de los últimos decenios, los pobres (LG 8c).

La consecuencia de esta situación ha generado un Sitz im Leben peculiar que ha convertido al cristianismo en una religión extra muros de ritos vacuos nada significativos para el hombre y, especialmente, de las mujeres de nuestro tiempo. Pruebas de esta infravaloración es una sobredimensión del rito, y por ende, una visión sacramentalista de la vida cristiana. Evidentemente, se percibe que los ritos hablan poco de su verdadera entidad. Necesitan ser explicados, por lo tanto, dejan de tener su fuerza significante. En 
el entramado de las sociedades suele haber nivelaciones y respuestas equilibradoras del sentido generalmente compartido. En el ámbito sacramental, la ritualización (significante) ha ido sustrayendo fuerza evocadora a la significación y esto ha devenido en una pérdida de referencialidad simbólica, de tal modo que el sentido originalmente metafórico o metonímico que expresaba el núcleo de "lo sacramental", tan evidente para las generaciones de fieles anteriores, ha ido degenerando en una progresiva e irremisible conciencia de cosificación de la praxis sacramental.

\subsection{DisTORSIÓN DEL SISTEMA DE MEDIACIONES RITUALES}

Como en muchos otros ámbitos de la experiencia humana, la pérdida de significatividad de un elemento ritual suele compensarse con el advenimiento de un nuevo modelo sociocultural, ajustado al nuevo imaginario espiritual imperante. Al dejar de estar operativo el sistema de unanimidad y por oposición a la marcha cultural y social, se produce una fuerte distorsión de las mediaciones que se traduce en una falta de fundamento, de ausencia de adhesión a una verdadera fe capaz de agostar el miedo a la perdición en el mundo, la ausencia de una salvación escatológica y la necesidad de salvación. Junto a esta distorsión general en el funcionamiento de las mediaciones rituales, convive la idea de las mediaciones como mecanismos propiciatorios gracias a las cuales le llega al hombre la salvación por vía automática. En la estructura tradicional la Iglesia hace de transmisión entre Dios y el hombre a modo de catalizador de la mediación religiosa. Los sacramentos son las canalizaciones por las que se llega a abastecer el hombre de la gracia divina. Como indica Martín Velasco (1994): "las mediaciones racionales se convierten en acatamiento doctrinal de la autoridad religiosa y las mediaciones activas en normas que hay que cumplir". ${ }^{37}$ En este sistema tan bien trabado la intervención de los sujetos es mínima, simplemente con acatar las imposiciones doctrinales interpuestas por los agentes sacramentales se cierra el círculo de la praxis sacramental. Todo este intervencionismo fijista redunda en una descomposición flagrante de las estructuras simbólicas y creativas en torno al componente simbólico de todo ritual y de los sacramentos en particular. Visto en perspectiva más amplia, constatamos que toda la superestructura fenomenológica de la religión

${ }^{37}$ Para distinguir estos dos tipos de mediaciones es interesante contrastar la información que transmite el propio MARTín Velasco (2007) Fenomenología de la Religión, Trotta: Madrid. 
sufre una mutación completa, pasivizando la acción de los sujetos religiosos, meros receptores de un mensaje distorsionado, que, procedente de una superestructura externa, sustituye la posición del Misterio por la institucionalización eclesiástica. El individuo ahora fundamenta su salvación en el sometimiento adhesivo a la doctrina sacramental interpuesta. El valor evocador del sacramento se confirma en la interpretación ex opere operato de lo que prescribe la norma sacramental, no en las posibilidades interpretativas del signo. Esta distorsión de las mediaciones necesita una re-educación para recuperar la vivencia sacramental como sacramentos, es decir, como acciones salvadoras de encuentro con el Misterio a través de su mismo significado. Lo ideal sería recuperar la eficacia sacramental en su sentido simbólico, de su efectividad soteriológica que sólo interviene a través del sacramento mismo: "signo visible de una realidad invisible" (P. RADBERTO). El simbolismo se ha visto replanteado por la acción de otros esfuerzos: (a) Institucionales: quizá se haya puesto excesivo esfuerzo en la explicación teológica en su aspecto institucional. Toda explicación teológica simplifica la significatividad libre y natural del sacramento. La formación pastoral, incluso en el marco del ciclo institucional del Bachillerato, tendría que replantearse los planteamientos y objetivos de la vivencia sacramental: su definición, encaje doctrinal y ejercitación de las medidas de transmisión pastoral. Eso sería el objetivo más deseable para alcanzar una plenificación interpersonal del encuentro mistagógico con el Misterio. (b) Tonalidades mágicas: elevadas las mediaciones por encima del hombre, todo hace que las mediaciones adquieran efecto soteriológico activo en manos del dispensador del sacramento, que se convierte en el único artífice, testigo y mediador de los dos polos del diálogo sagrado con el cumplimiento estricto de los formalismos normativos establecidos por la tradición o por la autoridad. La efectividad del acto simbólico se ha traslado al agente. Del ex opere operato pasamos sin solución de continuidad al ex opere operantis. En esencia, esto es un proceder lógico, pero llevado al extremo, puede aportar una especie de concepción mágica a la práctica sacramental.

Estas manifestaciones no dejan de ser epifenómenos de la distorsión sacramental que venimos aduciendo y que ha producido la escisión de lo sacramental del conglomerado de la actitud religiosa de los sujetos religiosos. Este afán controlador y de dominio de las instituciones religiosas tiene su réplica en la respuesta negativa de la sociedad, que, en su afán de independencia y autorrealización personales, contemplan como muy poco atractivo y peligroso para su aspiración de autonomía el sometimiento a unas mediaciones que son vistas como prefabricadas a las que se supedita su salvación individual. Sin embargo, sabemos que el hombre vive una vida his- 
tóricamente condicionada por la Trascendencia, por lo que el hombre ha buscado reencontrarse con el Misterio por los vericuetos que le ofrecen los NMR de eclosión espectacular en los últimos tiempos, la reinterpretación libérrima de la religiosidad popular u otras canalizaciones de lo religioso o pseudo-religioso distintas a las tradicionales, que resultan llamamientos mucho más motivadores para la vivencia religiosa de los sujetos religiosos de la actualidad en un contexto vital dominada por el predominio del pensamiento científico-técnico, refractaria, como lo es, a la adquisición automática ex opere operato de intervenciones sobrenaturales que no se pueden explicar empíricamente. Asimismo, la reconstrucción del imaginario creyente tras el postconcilio también ha facilitado la creación de un ideario sobre Dios no intervencionista, cuya imagen, desvirtuadora de los valores tradicionales, a veces muy pueriles y que incurren en un exceso de familiaridad del Encuentro con Dios, debe dar cuenta de las crisis de la "teodicea" contemporánea que observamos en las cicatrices del pasado siglo XX, e.g., del gran foso creado por el Dios "después de Auschwitz". ${ }^{38}$ Como ejemplo ilustrativo de esta tendencia, se observa que el Dios de la historia no puede ser un Dios intervencionista, sino un Dios "intencionista" que deja al hombre en su libertad creativa, vinculado a una ética de la responsabilidad $(\mathrm{H}$. JONAS) que resitúa la omnipotencia divina de manera autocomprometida y referida a la libertad humana (TorRes QueIRUGA). Ya no es, al decir de BONHÖFFER, un Dios Todopoderoso y Altísimo, sino que su grandeza más manifiesta adquiere el tamaño del débil e indigente del Bajísimo. Recuperar el sentido kenótico de la vivencia cristiana pueda ser una solución definitiva a la desmembración religiosa y de las mediaciones en el contexto actual. Estos elementos, ya señalados en el esbozo antropológico del comienzo, son, sin ánimo de exhaustividad, algunos de los condicionantes, culturalmente perceptibles, responsables de la descomposición sacramental a la que hemos asistido.

En el ámbito más estrictamente práctico, la mentalidad del pueblo considera a la Iglesia como un "lugar" donde se reciben los sacramentos, transformándose la recepción de los mismos en el criterio de pertenencia a la Iglesia. Se produce cada vez más una separación entre sacramento y vida, entre rito y compromiso existencial, entre celebración e implicación ética. En otras palabras, el sacramento se reduce a mero rito, a participación ru-

${ }^{38}$ Cf. METZ, J.B. (1979): La fe en la historia y la sociedad, Cristiandad: Madrid y MolTMANN, J. (2001): Cristo para nosotros hoy, Trotta: Madrid han valorado la recepción de la teología de Auschwitz como una nueva teodicea teológica, replanteando la eterna pregunta de ecos de Job: “¿dónde está Dios en el momento del sufrimiento de las víctimas inocentes?”. 
tinaria, mecánica, efectista, pero no efectiva, sin referencias ai incidencias vitales.

Por otro lado, la práctica ritual de una Iglesia institucionalizada, muchas veces ha promocionado hasta límites poco recomendables el papel del ministro que dispensa los sacramentos, convirtiendo el tono efectista ex opere operato en una mediación todavía más mediatizada por el papel individual del ministro (ex opere operantis) que confiere a la acción sacramental una verdadera función distorsionadora y no meramente mediadora.

\subsection{SUSTITUTOS ESPURIOS DE LAS MEDIACIONES HACIA LO SAGRADO}

Siguiendo a LUCKMANN (1972) y a MARDONES (2003) podemos llegar a la conclusión de que los sacramentos se han invisibilizado. ${ }^{39} \mathrm{La}$ falta de dominio socio-cultural de la Iglesia que, como se ha analizado en el parágrafo anterior, dispensaba la formulación, sentido, desarrollo y práctica de los sacramentos en un pasado más o menos reciente es una de las principales motivaciones de este análisis. Por otra parte, la fuerza impelente de la inercia de la vida contemporánea impone una rutina que acaba desactivando toda orientación soteriológica basada en el símbolo. Esta anulación se ve especialmente recrudecida en la relación con los símbolos "tradicionales" que son admitidos en el seno de una tradición de fe como lugar preeminente de la presencia de Dios. A estas mediaciones se les ha buscado sustitutivos pseudosimbólicos de lo sagrado como verdaderas mediaciones que auxilien al hombre en la búsqueda última de sentido. Repasemos algunos de estos placebos de sentido que han inundado una esfera de la psique y existencia humanas que había sido deslocalizada por la anemia simbólica de la praxis sacramental cristiana contemporánea, como indican los siguientes rasgos diferenciadores.

a) Excesos subjetivistas en la representación de las mediaciones que conducen al Encuentro con el Misterio. Muchas de ellas se asocian a algunos de los NMR que han sentado sus bases en otras tradiciones religiosas de corte oriental (budismo, yoga, etc.) que, pese a su aparato de sensibilización externa, imposibilitan el ejercicio de la dimensión simbólica obstaculizada por este tipo de prácticas psicologicistas, superficiales, posesivas, impersonales que alimentan únicamente la fe subjetiva, no la verdadera ad-

39 LuCKMAN, TH. (1972), La religión invisible, Sígueme: Salamanca. MARDONES, J.M. (2003): La vida del símbolo. La dimensión simbólica de la religión, Sal Terrae: Santander. 
hesión a la persona de Jesucristo, como visible lugar de la presencia de un Dios trascendente, como principio vital rector en nuestras vidas.

b) Espixitualidades laicas: se detecta toda una tendencia a la vivencia de las sabidurías y filosofías puramente inmanentes. Muchas de ellas hacen un uso casi lúdico del lenguaje y de las imágenes religiosas tradicionales, que evocaban una transgresión de sentido de los límites trascendentales del lenguaje religioso tradicional (incluidas las prácticas sacramentales) y las modelan en un marco de referencia inmanentista que, ciertamente, no provoca la explotación del símbolo. Este queda asfixiado en el lenguaje del usuario que utiliza, a su conveniencia, material religioso revestido de un tipo de uso intelectualista que irremisiblemente no deja de liquidar la fuerza significativa, performativa e implicativa del símbolo.

c) Inmanentismo de la experiencia religiosa. La religión sigue interesando al hombre de hoy, como no podía ser de otra manera, pero como símbolo inmanente que da sentido o que sirve para armonizar o iluminar la vida. Embotellados en el límite proposicional del lenguaje, la trascendencia a la que apunta el símbolo se queda en pura inmanencia y el Misterio de Dios es una mera referencia conceptual, que se cierra, en definitiva, ante la personal y abierta posibilidad de un Encuentro interpersonal con el Otro trascendente que nos permita salir de nosotros mismos. El juego de la experiencia culminativa de lo relacional que ofrece el Neuen Denken podría, como veremos, dar lugar a nuevas posibilidades de reinterpretación trascendental de los símbolos religiosos. No debe olvidarse que lo que hay de vivo en "el Misterio del culto cristiano" (CASEL) es la manifestación de Dios a los hombres a través de su plan de salvación. El enfoque hermenéutico relacional del Encuentro es indispensable para entender la participación del hombre en el Misterio de Dios. Esta participación no puede ser directa, sino que debe incluir los mismos mecanismos de funcionamiento propios de la densidad y del lenguaje simbólico. Parafraseando a RAHNER, podríamos decir que el cristianismo del mañana será simbólico o no será cristiano. El carácter místico podríamos revestirlo del adjetivo simbólico, pues parece obvio que si el acceso al Misterio no se produce por esas mediaciones, la relación directa entre sujeto y objeto religiosos se colapsa.

\subsection{RECONFIGURACIÓN DE LA TEOLOGÍA SACRAMENTAL}

La recomposición y distorsión del sistema de mediaciones en el mundo cristiano ha acelerado una revisión de las teologías sacramentales obligadas 
a renovar una interpretación cabal de los símbolos religiosos, que no entre en contradicción con el "mapa mental" que el medio configura a los sujetos religiosos de nuestros días. ${ }^{40} \mathrm{Se}$ observan dos tendencias contrapuestas que no son más que la cara de la moneda de un panorama sacramental que hemos expresado en el marco antropológico descrito. Una corriente teológica bastante bien instaurada ha insistido en una definición de los sacramentos como "signos sensibles y eficaces de gracia". Esto ha hecho que se extienda una imagen objetivista de los sacramentos, también conocida como eficacista, que tiene poco en cuenta al hombre como sujeto de los sacramentos y que carga las tintas sobre las condiciones de cumplimiento de los mismos. Los hombres no intervienen en el proceso de la recepción de la gracia, son entidades pasivas. Este modelo de interpretación sacramental aflora en un momento en el que la Iglesia se convierte en una mediación definitiva, en una institución ajena a las necesidades existenciales de sus miembros como sujetos religiosos activos, en buena medida, porque la pertenencia eclesial es el sacramento definitivo. Los sacramentos quedan encorsetados en un lenguaje sacral pseudoreligioso poco transparente para el hombre, anquilosados en imágenes no vigentes que poco o nada favorecen una legítima adhesión creyente (fides qua). La ceguera simbólica es el efecto natural del hombre, que se sitúa pasivamente ante el sacramento sin ninguna implicación en su vida. Como reacción a este objetivismo sacramental, ha ido fraguándose una visión subjetivista que pone el énfasis en el sujeto religioso y en su vivencia, en el entorno social, ritual y celebrativo de los mismos. Sin que pueda erigirse como solución de sentido definitiva, la propuesta podría ser un equilibrio que se sitúe entre ambos polos subjetivo y objetivo. Para ello, la misma tradición teológica nos da algunas pis-

${ }^{40}$ El concepto de "mapa mental" (semantic map o semantic network) procede de la lingüística cognitiva. El procesamiento lingüístico e intelectivo de la realidad extralingüística se organiza en la experiencia mediante analogías de sentido que permiten su clasificación por asociación de un haz de características prototípicas extraídas de una amplia diversidad de entidades. Contra SAUSSURE, la organización de este espacio mental no es arbitraria, sino que responde a una formalización universal que supere los límites de la propia percepción generada por el sujeto. Esta noción, nacida en el ámbito de la lingüística postgenerativa, puede ser útil en la descripción del fenómeno sacramental puesto que, expresado en signos analógicos representativos de la realidad, permitiría inferir patrones de comportamiento religioso, en este caso sacramental, de expresión universalmente uniforme. Además, esta visión permitiría integrar la relación sacramental en un marco más amplio de dominio de las categorías simbólicas que maneja el hombre en su aprehensión del medio. Algunas de las referencias clave de esta metodología cognitivista son : G. LAKOFF (1992) Metáforas we live by y LAKOFF Y JHONSON (1994) Cognitive Grammar, por otra parte, verdaderos pioneros en la aplicación de estas ideas. 
tas equilibradoras de la dimensión simbólica como mediaciones situadas entre fides quae y fides qua. Como señala explícitamente San Ireneo ( $A d v$. Her.3.24.1), el bautismo es el sacramento de la fe en Dios y aglutina tanto el sentido subjetivo (fides qua) como objetivo (fides quae) de esta. Las fórmulas de fe del Credo que en la liturgia el sacerdote nos entrega (Traditio Symboli) permanecen vigentes para reafirmar nuestra adherencia al cuerpo eclesial de Cristo (Redditio Symboli) y convertir en el bautismo al neófito en nueva criatura que renace mediante este alumbramiento simbólico ( $\phi \omega \tau \iota \mu \circ \varsigma)$ como una realidad nueva (Heb 6,4; Justino, Apol. 1.61-65; Dial. 122). Esta revitalización a la que impulsa el sacramento del bautismo supone una incorporación inquebrantable del bautizado a Cristo en su triple dimensión personal, eclesial y eucarística. Si esto es válido para la iniciación sacramental, parece legítimo extenderlo como un desiderátum en el intento profundizador de sentido y densidad del símbolo. En este esfuerzo reconfigurador de la teología sacramental resuenan con especial énfasis de sistematicidad las palabras de GONZÁLEZ DE CARDEDAL que por su carácter sintético merecen ser recogidas aquí con todo detalle. ${ }^{41}$

"A la Iglesia le son concedidos graciosamente los sacramentos, que fluyen de ella, como el sacramento primordial que es. El Vaticano II ha recuperado necesariamente esta visión unificadora de las realidades cristianas de gracia, otrora en ocasiones disgregadas. Cristo es el sacramento de Dios (Hebreos) y la Iglesia el sacramento de Cristo (LG SC, GS 42; AG 1): esta visión propia de los padres de la Iglesia es recuperada por los padres conciliares, ya había sido propuesta por otros como Möhler o Scheeben con anterioridad. En definitiva, si recuperamos la perspectiva central crística, los sacramentos constituyen la expresión de Su plenitud, que se infunde a los miembros de la Iglesia de acuerdo con sus situaciones de vida cristiana: nacimiento, crecimiento, decisiones sobre su papel en la vida, acercamiento del final. Los sacramentos son acciones de Cristo, "reliquias vivas de la Encarnación", los llamaron los Padres. En ellos es Cristo quien bautiza integrándonos en su muerte y resurrección; es Cristo, quien, como sacerdote supremo, presenta al Padre la ofrenda de su cuerpo y de su sangre a la cabeza de la Iglesia para vida del mundo; es Cristo quien por su santo Espíritu confiere el carisma de la verdad y de la autoridad a los sucesores de los apóstoles. Y Cristo nunca es separable de su Iglesia como no es separable la cabeza del cuerpo. Dios ha confiado su don de gracia y la revelación de su designio de salvación a la Iglesia. De ella recibe el creyente la fe por el sacramento del bautismo y por

41 GonZÁlez de CARdedAl, O. (2010), El quehacer de la Teología, Sígueme: Salamanca, pp. 384 y ss. 
los demás la sigue alimentando. La fe no es algo que el hombre ya posee y que atestigua en el bautismo como forma de incorporación a la Iglesia, sino que se recibe de Dios. No se tiene fe y por eso uno se bautiza para tener fe como principio nuevo de vida sobrenatural, ya que lo que se poseía antes sólo era la voluntad de creer, que evidentemente es necesaria como condición para recibir el don de Dios. Ahora bien, lo que es condición no es causa ni contenido".

\section{5.- A modo de conclusión}

En el umbral de la puerta de la fe transmitida, vivida y abierta a la esperanza de crecimiento, urge imperiosamente hacer un hueco a la virtualidad desfallecida que la arraiga simbólicamente, mediante una recuperación de la sensibilidad simbólica de un hombre enfermo de Trascendencia. El símbolo es capaz de agotar todas las posibilidades de presencialización de la distancia con el Otro. Confiere proximidad al perenne alejamiento de lo divino que sentencian muchas teologías del final de Dios. Subyuga a idéntico destino fatal al hombre. Como diagnóstico no exhaustivo, hemos ofrecido unas pautas que constatan el carácter debilitador del simbolismo antropológico contemporáneo retratadas en una variopinta paleta de contornos como tentativa esbozada del fenotipo antropológico estándar.

La vivencia religiosa de la práctica sacramental nos ha servido como catalizador de esa antropología. No hay nada más característico de una experiencia religiosa fértil y productiva que el acceso a un símbolo evocador, pluridimensional y polisémico que rinda culto a la inagotable fuente de sentido que mana del Misterio. La rehabilitación de esta frescura simbólica en la vivencia sacramental se sitúa, por tanto, como el punto de referencia y tarea ineludible de una religión que no pretenda quedar anulada en el nihilismo en que se ha convertido el fijismo doctrinal de prerrogativas morales y dogmas que anquilosan la proliferación de verdades religiosas insinuadas tras la imponente portada simbólica. Sin duda, el símbolo es parte decisiva del lenguaje religioso. Pues bien, en ese ámbito de la antropología, hemos detectado la presencia de fuerzas en tensión que desequilibran la correcta asimilación comunicativa del símbolo. A nuestro modo de ver, un correcto análisis aplicado a la desacramentalización que ofrecen los sacramentos contemporáneos, aquejados de falta de significatividad simbólica, se puede deber a la falta de una experiencia de la dimensión sagrada de la realidad determinada en la ausencia del cultivo de una racionalidad simbólica. 
El correcto cultivo de la razón simbólica como desmesura de toda experiencia humana, adolece de desequilibrios, pese a la paradoja preliminar que parece encerrar su formulación. Apuntalar esas tensiones es un objetivo real para orientar el Encuentro de mayor altura de la experiencia religiosa. El símbolo saturado encumbra toda dialéctica por designio divino. La desmesura por exceso o por defecto es una de las constantes reconocibles en la "vida del símbolo". Aludir a algunas de ellas, más allá de su repercusión en la práctica sacramental cristiana, que ya ha sido globalmente taquigrafiada (caps. 2 y, especialmente, 4 ), nos puede servir como coda epilogal a nuestra reflexión.

1) El SIMBolismo DE LA IGLESIA VS. EL DE LOS NMR

La capacidad simbólica oscila entre un subjetivismo psicologizante de influjos muy diversos y un objetivismo racionalista crudo. La religiosidad contemporánea se bandea entre ambas extrapolaciones. En el marco de la Iglesia católica todavía se percibe un mantenimiento de estructuras, correspondientes al comportamiento de una red institucional, en las que un rigorismo doctrinal y moral es celebrado en rituales desvitalizados por un exceso de lenguaje formal y de imperialismo conceptual de resabios fabulosos, pero poco penetrantes en la espiritualidad común. Frente a esta perspectiva de hermetismo, se posiciona una exacerbación en formato siempre de provisionalidad experimental, el subjetivismo psicologicista. La necesaria imaginación recrea por encima de lo recreable la experiencia religiosa que, en muchas ocasiones, dista mucho de ser identificada como piedra miliar de sentido religioso. Lo "sagrado" adquiere toques de profanidad exultante y los límites de rigor que permiten la discriminación de la experiencia sacramental se difuminan hasta emborronarse. Esta vivencia dionisíaca de lo religioso provoca la sensación de desorden $(\alpha \kappa o \sigma \mu \nu \alpha)$ y de contaminación de lo religioso.

2) LO SIMBÓLICO DE LO HUMANO Y LO DIVINO:TEOLOGÍA VS. ANTROPOLOGÍA SIMBÓLICAS

Este eje de la perspectiva simbólica no es exclusivo del problema de la sacramentología, sino que recorre toda la trayectoria de la historia del dogma. Bajo estos presupuestos, el sacramento-símbolo puede caer en la tergiversación total si no se actualiza una muy ponderada antropología sacramental, que bascula entre el enfoque jansenista que cree poder afirmar a costa de la divinidad humana, no venerando, en su justa medida, a los hombres como imágenes actualizadoras de Dios; o cuando, en la perspectiva contrapuesta, se incurre en un neopelagianismo que cree poder reali- 
zar el encuentro fraterno del hombre al margen de la gracia de Dios, incurriendo en esa idolatría de sentido.

Descubrir la entusiasta excelencia divinizadora en lo humano es una tarea que tan sólo puede realizarse si y sólo si las ramas encaramadas en la historia vislumbran la presencia del bosque divino. La genética sacramental de ese pequeño; gran misterio que es el hombre en su ejercicio activo debe sostenerse en el quicio de un mundo de lo reconocible que mide las leyes de la naturaleza y cifra su dominio en la explicación proporcional de lo empírico y la necesidad de un encuentro interior cada vez más evocador, que proporcione el viaje traslaticio a través de lo visible como meta de lo invisible, de la suma libertad y realización interpersonal con el Misterio. La articulación maestra de ambas dimensiones de lo humano traza la recta senda de salvación del sentido último de los sacramentos en el seno de la Iglesia, y del hombre instalado en su propia indagación mística de la experiencia de Dios en el mundo. 